\title{
Platelet-mediated modulation of fibrinolysis
}

Claire S. Whyte, PhD, Joanne L. Mitchell, MSc, Nicola J. Mutch, PhD

School of Medicine, Medical Sciences and Nutrition, Institute of Medical Sciences, University of Aberdeen, Aberdeen, UK.

Key words: platelets, fibrinolysis, factor XIII, plasminogen, fibrinogen

Word count main text: 4839

Word count abstract: 171

Nr of figures: 4

Nr of references: 176

\section{Corresponding Author:}

Dr Nicola J Mutch

School of Medicine, Medical Sciences and Nutrition

Institute of Medical Sciences

Foresterhill

University of Aberdeen

Aberdeen

AB25 2ZD

UK

Email: n.j.mutch@abdn.ac.uk

Tel: +44 1224437492

Short title: Platelet-mediated modulation of fibrinolysis 


\section{ABSTRACT}

Platelets are crucial to the hemostatic response. Their role in coagulation is well documented and they have been considered for some time to promote resistance of thrombi to fibrinolysis. Platelets confer resistance to lysis by promoting clot retraction of the immediate fibrin network and through release of PAI-1 from their $\alpha$-granules. However, recent developments in the field now indicate that the role of platelets in fibrinolysis is much more diverse. Indeed, recent studies of different subpopulations of platelets that develop upon activation suggest that platelets can play varied roles in regulating hemostasis. Likewise the developments in our understanding of thrombus formation, architecture and changes in fibrin deposition and composition suggest that these different subpopulations of platelets may populate distinct areas within thrombi and potentially dictate the local hemostatic balance in these areas. This review will discuss the diverse roles of platelets in fibrinolysis and highlight the recent developments in the field and the contribution of both the intracellular pool of modulators as well as the membrane surface in regulating these processes. 


\section{INTRODUCTION}

Platelets are at the nucleus of hemostasis, serving a multitude of functions to arrest bleeding and facilitate wound healing. Their vital role is evidenced by the fact that transfusion of platelets can dramatically restore hemostatic competency with higher platelet counts, correlating directly with an improvement in clinical bleeding. Interaction of platelets with the exposed components of the vessel wall post-injury generates the initial plug to limit blood loss. When platelets bind these matrix proteins they undergo rapid activation to release a host of clotting factors into the surrounding milieu. In addition, they change both the shape and composition of their membrane, allowing direct interaction with coagulation proteins. Platelets are a focal point for thrombin generation, interact directly with circulating fibrinogen facilitating generation of insoluble fibrin and act as an anchor for the growing scaffold of the clot. The crucial requirement of platelets for hemostasis is mirrored in the disease state of thrombosis where aberrant platelet function significantly augments thrombus formation with deleterious consequences. As a result, multiple antiplatelet agents are now used clinically to restrain the ability of platelets to participate in uncontrolled thrombus formation. ${ }^{1}$ Interestingly, in addition to their fundamental role of platelets in clot formation, they contain a host of fibrinolytic factors that regulate fibrinolysis. Until recently that role has been presumed to be antifibrinolytic due to the high concentrations of fibrinolytic inhibitors, contained within platelets. ${ }^{2-4}$ More recently additional profibrinolytic functions of platelets have been described which indicate that these unique anucleate cells may mediate fibrin dissolution as well as their established role in fibrin formation. ${ }^{5,6}$ This review will focus on the different means by which platelets can participate in the mechanisms that regulate fibrinolysis and recent work by our laboratory 
and others which suggest that platelets are central to regulation of both sides of the fibrinolytic process.

\section{Crosstalk between fibrinolysis and clot retraction}

The susceptibility of the fibrin network to lysis is dictated by its structure. ${ }^{7}$ Platelets actively compress and reduce clot volume via a process termed retraction thereby consolidating the integrity of the hemostatic plug. ${ }^{8}$ During clot retraction the fibrin network around the wound site is tightened via interactions with the integrin $\alpha \mathrm{llb} \beta 3$, previously termed platelet glycoprotein IIb/IIla. Upon platelet activation, $\alpha$ llb $\beta 3$ undergoes a conformational change and binds extracellular fibrinogen ${ }^{9}$ which initiates $\alpha$ llb $\beta 3$-mediated outside-in signalling. ${ }^{10}$ $\alpha \operatorname{llb} \beta 3$ is connected to the intracellular actin cytoskeleton via talin ${ }^{11}$ (Figure 1 ), allowing it to exert a contractile force on extracellular fibrin fibers. Platelet factor XIII-A (FXIII-A) modulates reorganization of the activated platelet cytoskeleton and $\alpha \mathrm{llb} \beta 3$ within sphingomyelin-rich lipid rafts, indicating that fibrin- $\alpha$ llb $\beta 3-m y o s i n$ act as an axis to support clot retraction. ${ }^{12}$

Retracted clots are resistant to fibrinolytic degradation ${ }^{13}$ and lyse more slowly than nonretracted clots ${ }^{14}$ due to condensing of cross-linked alpha- 2 antiplasmin $\left(\alpha_{2} A P\right)^{15}$ and reduced binding of tissue plasminogen activator (tPA) to fibrin. ${ }^{16}$ In platelet-rich clots the availability of plasminogen and plasminogen activators is reduced by clot retraction due to extrusion of these proteins. These studies indicate the integral role of platelets in clot retraction and how this impacts progression of fibrinolysis.

\section{$\alpha$-GRANULE PROTEINS}


There are three types of secretory granules, namely the $\alpha$-granules, dense granules and lysosomes (Figure 1). $\alpha$-granules are the most abundant with around $50-80$ per cell accounting for $10 \%$ of the platelet volume, in contrast dense granules comprise only $1 \% .{ }^{17}$ Upon activation platelets release more than 300 proteins the majority of these arising from $\alpha$-granules. $\alpha$-granule content is derived by several mechanisms including biosynthesis within their precursor cells megakaryocytes ${ }^{18-20}$, endocytosis ${ }^{21,22}$, and pinocytosis, ${ }^{23}$ at both the megakaryocyte and platelet level.

Differential packaging of $\alpha$-granule proteins including von Willebrand factor (VWF), fibrinogen, vascular endothelial growth factor, endostatin, thrombospondin-1, and basic fibroblast growth factor from specific $\alpha$-granule subpopulations has been reported. ${ }^{24,25}$ More intriguingly pro- and anti- angiogenic proteins were observed in distinct $\alpha$-granule populations and were differentially released..$^{25}$ Indeed, a similar mechanism for storage and release of pro- and anti- fibrinolytic proteins may potentially exist and warrants further investigation. In the remainder of this section we describe fibrinolytic proteins that are both endocytosed and biosynthesized within platelets and their contribution to fibrinolysis (Table 1).

\section{Fibrinogen}

Platelets have a pool of fibrinogen which is endocytosed from plasma into platelets and megakaryocytes ${ }^{26}$ and stored within $\alpha$-granules and the cytoplasm. Platelet fibrinogen accounts for $3-10 \%^{27,28}$ of total platelet protein $\left(5-25 \mathrm{mg} / 10^{11}\right.$ platelets) with approximately $25 \%{ }^{27}$ being found in $\alpha$-granules ${ }^{29,30}$. The integrin $\alpha$ llb $\beta 3$ is involved in endocytosis of fibrinogen, as patients with Type 1 Glanzmann thrombasthenia (who exhibit defective copy 
numbers of $\alpha$ llb $\beta 3$ ) have significantly reduced levels of fibrinogen within their platelets. ${ }^{31-33}$ In megakaryocytes, fibrinogen is endocytosed and trafficked to multivesicular bodies, which are precursors to mature $\alpha$-granules. ${ }^{34}$ There are potentially other receptors involved in the endocytosis of fibrinogen, such as the integrin $\alpha \mathrm{V} \beta 3$, which may facilitate binding of soluble fibrinogen to the inactive conformation of $\alpha \mathrm{llb} \beta 3$, thereby enhancing uptake of fibrinogen. ${ }^{35}$ Consistent with this hypothesis, deficiency of both $\alpha \mathrm{V} \beta 3$ and $\alpha \mathrm{llb} \beta 3$ further attenuates fibrinogen accumulation in platelets. ${ }^{36}$ Further work is required to define the receptors involved in the uptake of fibrinogen and its relative distribution within quiescent platelets. Both the cytosolic and $\alpha$-granule pools of fibrinogen are released in response to platelet stimulation 29,30 and is partially retained on the activated membrane due to its interaction with $\alpha$ llb $\beta 3$.

\section{Plasminogen}

Plasminogen has been identified in $\alpha$-granules by proteomic approaches ${ }^{37,38}$ but the relative amounts have not been defined, although it is reportedly released after stimulation ${ }^{39}$. Plasminogen is not detected in megakaryocytes, unless cultured in plasma containing plasminogen, indicating that it is endocytosed by the cells. ${ }^{38}$ There are two forms of plasminogen, the native predominant form Glu-plasminogen and the intermediate form Lysplasminogen, which is formed by cleavage of the activation peptide from Gluplasminogen. ${ }^{40}$ Glu-plasminogen is cleaved at Arg561-Val562 to form two chain Glu-plasmin followed by a further cleavage at the $\mathrm{N}$-terminus to form fully active lys-plasmin. ${ }^{40,41}$ Lys plasminogen has a more open conformation which is more readily activated by plasminogen activators. It is presently unknown whether the $\alpha$-granular pool is Glu- or Lys- plasminogen or if it differs from the plasma forms. 


\section{Inhibitors of fibrinolysis}

A number of fibrinolytic inhibitors exist within platelets and as a result of this platelet-rich thrombi are reportedly more resistant to tPA-mediated lysis than erythrocyte-rich thrombi. ${ }^{42}$ The platelet content of thrombi and their resistance to lysis may help to explain why recanalization in some stroke patients fails. ${ }^{43}$

\section{Plasminogen activator inhibitor-1 (PAl-1)}

The serine protease inhibitor, PAI-1, is the principal inhibitor of tPA and urokinase plasminogen activator (UPA). PAl-1 is abundant in $\alpha$-granules $\left(0.67 \mathrm{ng} / 10^{6}\right.$ platelets $)$ and is released upon platelet activation, accounting for the majority of circulating PAI- $1 .^{2}$ Platelets contain PAI-1 mRNA and are capable of de novo synthesis of functionally active PAI in vitro which largely remains in an active conformation. ${ }^{44,45}$ Platelet PAI-1 is functionally less active than the plasma PAI- $1,{ }^{2,46}$ but accounts for approximately $50 \%$ of total PAI- 1 activity due to its sheer abundance. ${ }^{2}$ Arterial thrombi which contain platelet dense regions ${ }^{47}$ found to contain 2-3-fold more PAl-1 than venous thrombi. ${ }^{48,49}$

\section{Alpha 2 antiplasmin $\left(\alpha_{2} A P\right)$}

$\alpha_{2} \mathrm{AP}$ is the principal inhibitor of plasmin and can be found within $\alpha$-granules. ${ }^{50,51}$ On average there is $62 \mathrm{ng} \alpha_{2} \mathrm{AP} / 10^{9}$ platelets which accounts for $0.05 \%$ of the plasma level on a volume basis. ${ }^{50}$ Platelet $\alpha_{2} \mathrm{AP}$ is released upon activation ${ }^{50}$ and stabilizes platelet-rich clots against fibrinolysis. ${ }^{52,53}$ The contribution of the platelet pool of $\alpha_{2} \mathrm{AP}$ to thrombus stability may be limited, as addition of normal circulating platelet concentrations to $\alpha_{2} A P$-depleted plasma does not stabilize thrombi against lysis. ${ }^{54}$ Platelet $\alpha_{2} A P$ may potentially play a role in 
maintaining the structural integrity of the platelet plug by down-regulating lysis during the initial stages of thrombus formation, rather than protecting the established thrombus against premature lysis.

\section{Thrombin activatable fibrinolytic inhibitor (TAFI)}

TAFI is a pro-carboxypepetidase that can be activated by thrombin, a reaction that is accelerated in excess of 1000 -fold by thrombomodulin ${ }^{55}$ or alternatively by plasmin. ${ }^{56}$ The activated carboxypepetidase, TAFla, removes C-terminal lysine residues from fibrin that has been partially degraded reducing the availability of binding sites for tPA and plasminogen. ${ }^{57}$ TAFI is present in platelets at approximately $50 \mathrm{ng} / 10^{9}$ platelets and is released from $\alpha$ granules upon activation ${ }^{4}$ in concentrations sufficient to down-regulate fibrinolysis of platelet-rich thrombi. ${ }^{58}$ Megakaryocytes contain TAFI mRNA and biosynthesis of this protein is thought to account for the pool of TAFI residing in $\alpha$-granules. ${ }^{4,58}$

\section{Histidine rich glycoprotein (HRG)}

The plasma glycoprotein HRG plays a role in multiple physiological processes including coagulation and fibrinolysis. HRG is endocytosed by platelets and megakaryocytes ${ }^{59}$, with this pool accounting for $0.14 \%$ of the plasma level. ${ }^{60} \mathrm{HRG}$ is released upon platelet activation $^{59,60}$ and directly associates with the membrane of activated platelets. ${ }^{61}$ Interestingly, $\mathrm{HRG}^{-/-}$mice exhibit longer tail bleed times, indicative of defective platelet activation, increased antithrombin activity, shorter prothrombin times and enhanced spontaneous fibrinolysis. ${ }^{62}$ As HRG is known to bind to fibrinogen ${ }^{63}$ and is retained on the fibrin surface after clot formation ${ }^{64}$, co-localization with fibrinogen in $\alpha$-granules mean they could potentially be released as a complex following stimulation. HRG also acts as an 
competitive inhibitor of plasminogen by binding to lysine binding site 1 , potentially downregulating association of plasminogen and fibrin. ${ }^{65}$ Conversely, it is reported to tether plasminogen to the cell-surface, thereby enhancing the migratory potential of cells. ${ }^{66}$ Further work is required the significance of this protein in regulating fibrinolysis.

\section{Platelet C1-inhibitor}

C1-inhibitor is a serpin which inhibits serine proteases of the complement, contact, and fibrinolytic systems. C1-inhibitor is contained in $\alpha$-granules ${ }^{67}$ and is secreted upon activation with a portion (23\%) retained on the membrane. ${ }^{3}$ The platelet pool of C1-inhibitor is derived from megakarocyte biosynthesis with platelets containing $62 \mathrm{ng} / 10^{8}$ platelets compared to the relatively high plasma concentration of $290 \mu \mathrm{g} / \mathrm{ml} .{ }^{3} \mathrm{C} 1$-inhibitor forms a complex with tPA in situations when it is in excess over PAI-1. ${ }^{68-70} \mathrm{~A}$ recent report suggests that C1-inhibitor is the principal inhibitor of a single-site, Lys300 $\rightarrow$ His mutant (M5) form of scuPA, which is less vulnerable to non-specific activation to uPA. ${ }^{71}$ Infusion of C1-inhibitor prior to administration of the mutant form of scuPA prevented non-specific activation of plasminogen and fibrinogenolysis whilst permitting lysis of partially-degraded fibrin. ${ }^{72}$

\section{Protease nexin-1 (PN-1)}

Protease nexin-1 (PN-1), also called serpinE2, is a serpin inhibitor with a broad spectrum of substrates including thrombin, factor $\mathrm{Xa}$, factor Xla and activated protein $\mathrm{C}$, as well as the fibrinolytic proteins plasmin, tPA and uPA (reviewed by ${ }^{73}$ ). Interestingly, PN-1 is the closest homologue of $\mathrm{PAl}-1^{73}$ eluding to a function in regulation of fibrinolysis. It is expressed by most blood cells including platelets ${ }^{74,75}$ where the majority is contained within $\alpha$-granules, but a small amount exists on the quiescent platelet membrane. ${ }^{76}$ The concentrations of PN- 
1 released in the secretome are relatively high $\left(20 \mathrm{nmol} / \mathrm{L} \text { per } 3 \times 10^{8} \text { platelets }\right)^{73}$ but a pool is retained on the activated membrane surface. ${ }^{74}$ Platelet PN-1 has the capacity to inhibit both tPA-mediated fibrinolysis and directly down-regulates plasmin generation and activity on fibrin. ${ }^{77}$ A blocking antibody to $\mathrm{PN}-1$ enhances lysis of platelet-rich clots and $\mathrm{PN}-1^{-1-}$ mice exhibit accelerated lysis compared to wild-type. ${ }^{77}$ Indeed, a deficiency in PN-1 significantly augments t-PA mediated thrombolysis ${ }^{77}$ emphasizing its clear inhibitory role in fibrinolysis.

\section{DENSE GRANULES}

Dense granules (or dense bodies) are less abundant than $\alpha$-granules, with only around 6-8 per platelet, at around $250 \mathrm{~nm}$ in size, and are identified in electron micrographs by virtue of their electron dense cores. Dense granules are comprised of cations $\left(\mathrm{Ca}^{2+}, \mathrm{Mg}^{2+} \mathrm{K}^{+}\right)$, phosphates (polyphosphate (polyP) and pyrophosphate), bioactive amines (serotonin and histamine) and nucleotides (ATP, ADP, UTP, GTP). High concentrations of these constituents are achieved by active transport mechanisms which also maintains the granule lumen at a $\mathrm{pH}$ of around 5.4. The components of dense granules, in particular serotonin, $\mathrm{ADP}, \mathrm{Ca}^{2+}$ and polyP regulate hemostasis, which will be described in more detail below.

\section{Polyphosphate (polyP)}

PolyP is an inorganic phosphate molecule comprising of a repeating units of phosphate monomers joined by phosphoanhydride bonds. ${ }^{78} 79$ 79,80 PolyP elicits numerous effects on coagulation and fibrinolysis inducing significant augmentation of the clotting process by enhancing factor XII (FXII) activation, preventing inhibition of factor Xa (FXa) by tissue factor pathway inhibitor (TFPI), and acting as a cofactor for thrombin-mediated activation of factor $\mathrm{XI}$ (FXI). ${ }^{81}$ These procoagulant effects have a downstream impact on fibrinolysis by 
enhancing TAFla activation due an acceleration of thrombin generation. ${ }^{81}$ Polymer length is an critical determinant of polyP function; longer polymers are significantly more effective in activation of FXII. ${ }^{82}$ PolyP binds to fibrinogen ${ }^{83}$ and alters the structure of the fibrin network, in doing so it attenuates binding of tPA and plasminogen to fibrin, thereby delaying tPAmediated fibrinolysis. ${ }^{83}$ PolyP binds to $\mathrm{FXII}^{80,84}$ facilitates its autoactivation ${ }^{84}$ and has been shown to augment FXII-driven coagulation. ${ }^{81,85}$ Despite being classified as a coagulation factor, activated FXII (FXIla) demonstrates weak plasminogen activator activity. ${ }^{86,87}$ Recently, it has been shown that FXIla can augment tPA-mediated fibrinolysis by generating additional plasmin. ${ }^{88}$ Our recent work has shown that polyP can activate $\mathrm{FXII}{ }^{84}$ and subsequently acts as a cofactor in enhancing its plasminogen activator activity which is the first profibrinolytic function of polyP to be documented.

\section{CYTOPLASMIC PROTEINS}

\section{Factor XIII (FXIII)}

Activated FXIII (FXIIla) increases the mechanical stability of clots by forming $\varepsilon$-( $\gamma$-glutamyl) lysyl bonds in fibrin ${ }^{89}$ through cross-linking the lysine $\varepsilon$-amino group of one fibrin strand to the glutamine $\gamma$-carboxymide group of another. ${ }^{90}$ FXIII is present in platelets ${ }^{91-93}$ at high concentrations (around $60 \mathrm{fg}$ per platelet) ${ }^{94}$ and is largely contained within the cytoplasm. ${ }^{29,95}$ Unlike the heterodimer $\mathrm{A}_{2} \mathrm{~B}_{2}$ form that circulates in plasma, the cellular form exists as a homodimer of FXIII-A. ${ }^{29,95}$ A small pool of the $A_{2} B_{2}$ form is reported to be contained in $\alpha$-granules ${ }^{29,96}$ which is presumed to be taken up from plasma in association with fibrinogen ${ }^{96}$ Early studies indicated that FXIII-A is retained in the platelet cytoplasm following activation and is not detectable in the secretome. ${ }^{97}$ FXIII-A does not contain an identifiable endoplasmic reticulum (ER) signaling sequence and is excluded from the ER- 
Golgi pathway in nucleated cells. ${ }^{98}$ However, it has been found to be directed toward the plasma membrane in association with Golgi vesicles in monocyte-macrophages. ${ }^{99}$ Due to the lack of ER-leader sequence FXIII-A cannot be targeted to $\alpha$-granules in nascent platelets during de novo synthesis in megakaryocytes. This evidence has led to the assumption that release of FXIII-A from platelets was improbable and its functions were likely to be intracellular and distinct from the role of the plasma FXIII in hemostasis. Plasma FXIII plays an essential role in the regulation of fibrinolysis where it cross-links inhibitors of fibrinolysis to fibrin, including $\alpha_{2} \mathrm{AP}^{100}, \mathrm{TAFI}^{101}$, and PAI-2. ${ }^{102}$ We have shown that the antifibrinolytic function of plasma FXIIla is mediated by cross-linking $\alpha_{2} A P$ to fibrin ${ }^{103}$ and in its absence thrombi lyse rapidly. ${ }^{104}$ Platelet FXIII-A was shown to induce high molecular weight $\gamma$-dimer, $\alpha$-polymers and $\alpha_{2}$ AP-fibrin cross-links. ${ }^{52,53,105-107}$ Our work has now shown that platelet FXIII-A is externalized on the activated platelet membrane and mediates extracellular fibrin cross-linking reactions stabilizing thrombi against fibrinolysis in an $\alpha_{2} \mathrm{AP}$-dependent manner. ${ }^{54}$

\section{Tissue factor pathway inhibitor (TFPI)}

Two alternatively spliced isoforms of TFPI exist in blood: TFPI $\alpha$ and TFPI $\beta .{ }^{108,109}$ Platelets exclusively express the TFPI $\alpha$ isoform which is derived from megakaryocytes and accounts for approximately $7-10 \%$ of the total pool of TFPI in whole blood. ${ }^{110,111}$ At this time, it is unknown where TFPI $\alpha$ is located within quiescent platelets but evidence suggests it is not found in $\alpha$-granules or lysozymes, as it does not co-localize with VWF, fibrinogen, or lysosomal-associated membrane protein-1 (LAMP-1). ${ }^{110}$ TFPI $\alpha$ is exposed on the surface of platelets following strong stimulation with thrombin or dual agonists via an unknown mechanism. ${ }^{110}$ In addition to platelet surface expression, a soluble form of TFPI is released in 
response to strong agonist stimulation, allowing accumulation of the inhibitor at sites of vascular injury to act directly on tissue factor/factor VIla complex and attenuate thrombus propagation. TFPI-2, a homologue of TFPI-1, has recently been identified within platelets and is of megakaryocytic origin. ${ }^{112}$ TFPI- 2 is released from platelets in response to TRAP-6 stimulation and strongly attenuates tPA-mediated plasma clot lysis by directly inhibiting plasmin. The levels of TFPI-2 rise steadily during pregnancy potentially indicating an antifibrinolytic role for this kunitz inhibitor in control of bleeding during labour. ${ }^{112}$

\section{FIBRINOLYTIC PROTEINS ON THE MEMBRANE SURFACE}

The activated membrane surface of platelets is well documented in terms of its binding of coagulation factors, via Gla-domains and integrin binding to fibrinogen, VWF, and collagen. Perhaps less well explored is the ability of the platelet membrane to serve as a binding site for fibrinolytic proteins.

\section{Urokinase plasminogen activator (UPA)}

The plasminogen activator uPA is a $54 \mathrm{kDa}$ serine protease found in urine and synthesized by fibroblast-like cells, monocytes, macrophages ${ }^{113,114}$, and epithelial cells. ${ }^{115}$ The single chain form of UPA, scuPA, is activated to two chain uPA by cleavage at Lys158-Ile159. ${ }^{116}$ Normal platelets contain a small amount (1.3 ng uPA $/ 10^{9}$ platelets) of uPA ${ }^{117}$ but negligible levels are found in megakaryocytes. Quebec platelet disorder is associated with enhanced expression and storage of UPA and manifests as delayed onset of bleeding after injury. Increased expression of uPA, develops during differentiation of megakaryocytes from hematopoietic progenitors and is linked to a tandem duplication in the PLAU gene. ${ }^{38}$ The limited plasminogen activator concentration in normal platelets may serve a protective 
function, as Quebec platelet disorder results in intracellular generation of plasmin which is associated with degradation of $\alpha$-granule proteins. ${ }^{118}$

In sharp contrast to the inhibitory effect of platelets on t-PA- and uPA-mediated fibrinolysis we and others have shown that scuPA-mediated lysis is dramatically enhanced by platelets. 5,119 This seems counterintuitive considering the high concentrations of fibrinolytic inhibitors in platelets, but is explained by surface-mediated reciprocal activation of plasminogen and scuPA on the membrane surface. ${ }^{5}$ scuPA is present on the membrane of unstimulated platelets ${ }^{120}$, however binding is not accounted for by the known cellular receptor UPAR ${ }^{121}$, as uPAR is not expressed on platelets. Exogenous scuPA is endocytosed by platelets, by an underdetermined mechanism, which may prolong its activity. ${ }^{122}$ Once formed, cell-bound plasmin is protected from inhibition by $\alpha_{2} A P$, although (sc)uPA is susceptible to inhibition by PAI-1 and PAI-2. An additional mechanism of activation of thrombin-cleaved scuPA by platelet cathepsin $\mathrm{C}$ has also been described on the surface of thrombin-stimulated platelets. ${ }^{123}$ Despite these lines of evidence locating (sc)uPA on the membrane of quiescent and activated platelets, the receptors responsible are still unknown.

\section{Tissue-type plasminogen activator (tPA)}

tPA, a $68 \mathrm{kDa}$ serine protease, is largely produced and secreted by endothelial cells ${ }^{124}$ however, small amounts of active tPA have been detected in megakaryocytes. ${ }^{125}$ tPA is secreted as a single-chain form (sctPA) that is cleaved at Arg275-Ile276 to a two-chain form (tctPA). When associated with fibrin, both forms exhibit comparable activity, ${ }^{126}$ as binding of sctPA to fibrin decreases the Km of activation, enhancing plasmin generation and downstream fibrinoysis. ${ }^{127}$ tPA binds to the surface of quiescent platelets potentiating 
plasminogen activation approximately 8 -fold. ${ }^{128,129}$ Reversible binding of tPA to the membrane appears to be by a single-class of saturable, low affinity binding sites that are amplified upon thrombin stimulation and partially displaced by plasminogen. ${ }^{129,130}$ Receptors for tPA on platelets have not been definitively identified, but annexin II has been described as a plasminogen-tPA co-receptor on endothelial cells. ${ }^{131}$

Platelet-rich regions within clots are associated with densely packed retracted fibrin fibers which attenuate tPA binding and decrease lysis front velocity. ${ }^{16,132}$ Interestingly, a second late phase acceleration of fibrinolysis is observed which is attributed to clustering of lysing fibers which augments the local concentration of fibrin-bound tPA. ${ }^{132}$ The relative contribution of fibrin versus the cell surface in accelerating local fibrinolysis is an intriguing question but one that is difficult to tackle experimentally.

\section{PLATELET SUBPOPULATIONS}

Upon activation of platelets, a number of phenotypically different subpopulations arise ${ }^{133-}$ ${ }^{136}$ which have different functions within the microenvironment of the thrombus. Procoagulant platelets express phosphatidlyserine $(P S)^{137}$, readily binding coagulation factors, thereby enhancing thrombin generation and downstream fibrin formation. Adherent platelets expose activated $\alpha \mathrm{llb} \beta 3$, bind fibrin and other platelets thereby consolidating the thrombus and protecting against premature degradation. ${ }^{138}$

\section{Aggregating platelets}

Aggregating platelets are PS-negative with a characteristic spread morphology (Figure 2A). They bind fibrinogen via activated $\alpha \mathrm{llb} \beta 3$ and generate fibrin on their surface. ${ }^{138}$ 
Aggregating platelets expose FXIII-A in a diffuse pattern over their surface ${ }^{54}$, whilst plasminogen and PAI-1 localize centrally over the granulomere (Figure 3). ${ }^{6}$ Binding of plasminogen is attenuated by blocking $\alpha \mathrm{llb} \beta 3$ with tirofiban, however it is not dependent on the active conformation of the integrin. This is evidenced by the fact that plasminogen accumulates on the surface of aggregating platelets prior to PAC-1 antibody which binds only the active integrin. ${ }^{6}$ The functional significance of these fibrinolytic proteins in aggregating platelets requires further clarification. However, their importance in thrombus architecture and stability is exemplified by addition of abciximab, a $\alpha$ llb $\beta 3$ receptor antagonist, which significantly accelerates lysis by prohibiting the interaction between fibrin(ogen) and platelets. ${ }^{139}$

\section{PS-exposing platelets}

Upon exposure to a collagen surface or glycoprotein VI ligands, platelets initially form pseudopods and lamellipodia before morphing to a characteristic 'balloon' shape and flipping PS to the activated membrane (Figure 2B). ${ }^{140}$ PS-exposing platelets, or procoagulant platelets, exhibit prolonged increases in cytosolic $\mathrm{Ca}^{2+}$ and support binding of the prothrombinase complex. ${ }^{136,138,141}$ After the appearance of aggregating platelets, which incorporate fibrinogen, further platelets are recruited that subsequently become PSpositive. ${ }^{138}$ These platelets allow formation of 'star-like' fibrin network which emanates from the platelet surface under low shear. This process is dependent on both FXIIIa and $\alpha \mathrm{llb} \beta 3^{142}$, as in their absence fibrin fibers orientate in the direction of flow. ${ }^{143}$ These observations indicate that PS-exposing platelets contribute to the dynamic structure of the fibrin network by guiding multi-directional fibrin polymerization and may have downstream consequences in terms of modulating fibrinolysis. Platelet FXIII-A and calpain have a role in 
limiting excessive accumulation of platelets by decreasing adhesion via $\alpha \mathrm{llb} \beta 3 .{ }^{134}$ Interfering with PS exposure on platelets impairs FXa and thrombin generation thereby downregulating thrombus formation in murine models of thrombosis. ${ }^{144,145}$ These thrombi are prone to embolization, exhibit reduced stability and increased susceptibility to lysis

\section{Coated platelets}

'Coated platelets' are procoagulant platelets produced by strong dual agonist stimulation. ${ }^{133,146,147}$ Coated platelets retain a 'coat' of cross-linked $\alpha$-granule proteins on their surface ${ }^{143,146,148}$ which is reported to develop secondary to PS exposure. ${ }^{149}$ The protein coat consist of procoagulant proteins such as factor V, VWF, and fibrinogen which are reportedly cross-linked to the surface in a FXIIla-dependent manner. The presence of fibrinolytic proteins such as PAI-1, HRG, and plasminogen on coated platelets is less well described, but they too could be present within the 'coat'. The percentage of coated platelet potential in individuals ranges from $15-53 \% .1{ }^{147}$ The full physiological role and capacity of coated platelets is not fully understood, however, they are thought to be prothrombotic in nature. ${ }^{150}{ }^{151}$ Therefore, the ability to target and enhance the profibrinolytic potential of this subpopulation may have therapeutic value.

\section{Protruding 'cap' on procoagulant platelets}

Procoagulant PS-exposing platelets have been found to possess a protruding 'cap' which is rich in fibrinogen and thrombospondin. ${ }^{152}$ We have recently confirmed the presence of fibrinogen and demonstrated the localization of FXIII-A ${ }^{54}$, plasminogen, and PAI- $1^{6}$ in these protruding caps (Figure 3). These 'caps' have since been demonstrated to contain numerous coagulation factors IXa, Xa/X, Va and VIII. ${ }^{153}$ Fibrin may act as an anchor for these 
proteins within the platelet 'cap' and could potentially facilitate the transfer of plateletderived proteins into the adjoining fibrin network. Indeed activation of platelets with TRAP6 rather than thrombin or inhibition of fibrin polymerization with Gly-Pro-Arg-Pro reduced exposure of platelet FXIII-A $\mathrm{A}^{54}$ and attenuated plasminogen binding within the 'cap'. ${ }^{6}$ However, despite the presence of fibrin(ogen), $\alpha$ llb $\beta 3$ appears to be in an inactive conformation. Platelets stimulated with strong dual agonists display secondary inactivation of the integrin after occupation with a ligand such as fibrinogen. ${ }^{134,146,154,155}$ Blocking $\alpha$ llb $\beta 3$ or fibrin polymerization reduces plasminogen binding to PS-exposing platelets ${ }^{6}$ and consistent with this Glanzmann thrombasthenia patients who lack $\alpha$ llb $\beta 3$ display reduced plasminogen binding. ${ }^{156}$

These protein rich 'caps' on the surface of PS-exposing platelets are not fully understood but their collection of fibrinolytic mediators implies a functional role in fibrinolysis. Within a developing thrombus, the PS-exposing platelets are visualized as distinct non-aggregating platelets that localize in strings at the edges of clots ${ }^{138}$ and may limit excessive clot expansion by curbing association of additional platelets while permitting further generation of fibrin. The collection of proteins in these protruding 'caps' suggest they may act as a delivery service for fibrinolytic proteins into the heart of the thrombus.

\section{THROMBUS ARCHITECTURE, LOCALIZATION OF PLATELETS AND FIBRINOLYTIC PROTEINS}

During thrombus formation a core of densely packed, highly activated platelets forms which is enveloped by a shell of loosely packed less activated platelets. ${ }^{157}$ The rate of solute transport within the core of the thrombus is low $^{158}$ indicating that proteins associated with the platelet membrane or within the gap junctions of these tightly packed aggregates will be 
retained. These platelets experience strong agonist stimulation evoking prolonged intracellular calcium spikes, shape change and rapid degranulation. ${ }^{159}$ In the shell of the thrombus, platelets are less intensely stimulated, displaying only transient increases in intracellular calcium with little or no degranulation. ${ }^{159}$ This is an important concept, as it indicates that platelets do not release their intracellular contents into flowing blood, but rather into the body of the thrombus where local concentrations of platelet-derived proteins are likely to define the hemostatic balance.

Upon thrombin stimulation the copy number of $\alpha$ llb $\beta 3$ on the membrane increases 2-3-fold, presumably drawing from the pool within $\alpha$-granules. ${ }^{160}$ The concurrent sharp rise in intracellular $\mathrm{Ca}^{2+}$ induces the active conformation of $\alpha \mathrm{llb} \beta 3^{161}$ and interaction with fibrinogen. ${ }^{9}$ Thrombin concentrations are elevated within the core of the thrombus facilitating further fibrin formation and platelet activation thereby dictating the overall structure and its resistance to fibrinolysis.

Plasminogen associates with unstimulated platelets, but following thrombin stimulation binding is significantly augmented in a fibrin and $\alpha$ llb $\beta 3$-dependent manner. ${ }^{6,162,163} \mathrm{An}$ array of plasminogen receptors have been identified on different cell types and generally involve an interaction of plasminogen with C-terminal lysine residues of membrane-bound proteins. ${ }^{164}$ The plasminogen content of a thrombus dictates its susceptibility to lysis ${ }^{165}$ and is likely related to its ability to be retained on the surface of fibrin and cells. Our laboratory studied the localization of plasminogen in a physiological flow model of thrombus formation and lysis. ${ }^{6}$ Plasminogen accumulated on platelet-associated fibrin, with a smaller pool found in direct association with the platelet surface (Figure 4). ${ }^{6}$ Plasminogen was initially 
visualized in the 'core' of the thrombus in direct association with platelets, but as time progressed it was evident at areas distal to the core localizing with fibrin; both fibrin and plasminogen accumulation in these areas was blocked by inclusion of hirudin during thrombus formation. ${ }^{6}$ Using this flow model we have shown that both fibrin and cellular surfaces are important for retention of plasminogen within thrombi and that its local concentration governs the rate of fibrin degradation.

Stimulation of platelets with strong dual agonists, thrombin and convulxin, generates measurable quantities of plasmin which is significantly augmented by addition of plasminogen activators. ${ }^{6}$ We have previously shown a relationship between plateletassociated plasminogen and scuPA ${ }^{5}$, as described earlier in this review. Cell-bound uPA recognizes and activates both lys-plasminogen and $\varepsilon A C A$-liganded plasminogen, which has an open conformation similar to lys-plasminogen. ${ }^{166}$ Association of plasminogen with the platelet surface induces an open conformation which is more readily cleaved to plasmin..$^{5,162,166-169}$ Platelet-bound plasminogen can also be activated by crosstalk with uPA bound to monocytes or endothelial microparticles. ${ }^{166}$ tPA-mediated plasminogen activation is also enhanced by platelets and is thought to arise from an autocatalytic mechanism. ${ }^{168} \mathrm{In}$ addition to the surface enhancement of plasminogen activation, the platelet surface acts as a reservoir of plasmin that is protected from inhibition by $\alpha_{2} \mathrm{AP}$ thereby promoting fibrinolysis. ${ }^{170,171}$

PAI-1 accumulates to high concentrations in platelet-rich thrombi ${ }^{49,165}$ and its concentration directly correlates with their lysability. ${ }^{165,172}$ PAI-1 is not cross-linked to fibrin like $\alpha_{2} A P$, but associates indirectly via its cofactor, vitronectin ${ }^{173}$, which also preserves the activity of this 
labile serpin inhibitor. ${ }^{174,175}$ Upon release from $\alpha$-granules PAI-1 localizes on platelet-bound fibrin thereby increasing the local resistance of this network to fibrinolytic degradation. ${ }^{176}$ TAFI is also released from $\alpha$-granules in response to stimulation ${ }^{4,6}$ and exerts an additional antifibrinolytic function to that of the plasma pool. ${ }^{58}$ Thrombin generation on the platelet membrane and concomitant release of TAFI with platelet-derived TM ${ }^{177}$, may accelerate generation of TAFla in platelet-rich areas. Plasmin activity generated on the surface of activated platelets ${ }^{6}$ may also function in local TAFI activation and indeed our laboratory has previously shown that both thrombin/TM and plasmin-mediated TAFI activation regulate thrombus lysis. ${ }^{178}$ TAFla has also been found to play a significant role in resistance of platelet-rich clots to lysis. ${ }^{179}$ Indeed, dual targeting of PAI-1 and TAFla using antibody approaches has shown to be beneficial and is currently under investigation as novel thrombolytic agent for the prevention of ischaemic stroke. ${ }^{180,181}$

Platelet FXIII-A stabilizes thrombi against fibrinolysis by cross-linking $\alpha_{2} A P$ to fibrin of plasma and platelet origin.$^{52,53,105}$. These extracellular cross-linking reactions are achieved by translocation of FXIII-A from the cytoplasm to the outer-leaflet of the stimulated platelet membrane. FXIII-A is not detected in the secretome indicating that externalization to the membrane is sufficient for the transglutaminase to mediate extracellular cross-linking reactions. ${ }^{54}$ The distribution of FXIII-A on the surface of platelets differed in relation to the subpopulation and further work is necessary to determine which of these is important for mediating the antifibrinolytic function of FXIII-A. ${ }^{54}$

\section{FINAL REMARKS AND PERSPECTIVES}


Traditionally platelets were considered antifibrinolytic in nature, but their ability to harbor plasminogen, plasminogen activators, and functional plasmin on their surface mean that their role is more complex than initially perceived. Platelets are a heterogeneous population of cells that exist in different activated states, reflected in their membrane composition and morphology, and as a consequence expose different receptors, molecules and proteins on their surface. Recent advances in defining the subpopulations of platelets and the profile of fibrinolytic proteins retained on their membrane surface, or on platelet-bound fibrin, may provide clues as to how these platelets function under different conditions. Whether differential packaging and release of pro- and anti-fibrinolytic proteins from $\alpha$-granules contributes to regulation of fibrinolysis in different settings remains to be established. Time-dependent surface expression of platelet-derived proteins and binding of exogenous plasma-derived proteins may impact on the function of these complex cells on fibrinolysis. Understanding the function of platelet subpopulations could allow for thrombolytic therapies to be tailored to target populations. A recent report showed that thrombolysis with scuPA fused to single chain antibody fragments (scFv), which target activated $\alpha_{\| \mathrm{lb}} \beta_{3}$, was dependent on platelet-bound plasminogen. ${ }^{182}$ The possibility that platelets could serve in the rapid delivery of specific pro- or anti-fibrinolytic protein packages provides an exciting opportunity to harness their potential therapeutic value.

\section{ACKNOWLEDGEMENTS}

This research was supported by grants FS/11/2/28579 (NJM) and PG/15/82/31721 (NJM \& CSW) from the British Heart Foundation and the University of Aberdeen Development Trust (N.J.M., J.L.M.). 


\section{REFERENCES}

1. Capodanno D, Ferreiro JL, Angiolillo DJ. Antiplatelet therapy: new pharmacological agents and changing paradigms. J Thromb Haemost. 2013;11 Suppl 1:316-329.

2. Booth NA, Simpson AJ, Croll A, Bennett B, MacGregor IR. Plasminogen activator inhibitor (PAI-1) in plasma and platelets. Br J Haematol. 1988;70(3):327-333.

3. Schmaier AH, Amenta S, Xiong T, Heda GD, Gewirtz AM. Expression of platelet $\mathrm{C} 1$ inhibitor. Blood. 1993;82(2):465-474.

4. Mosnier LO, Buijtenhuijs P, Marx PF, Meijers JC, Bouma BN. Identification of thrombin activatable fibrinolysis inhibitor (TAFI) in human platelets. Blood. 2003;101(12):4844-4846.

5. Baeten KM, Richard MC, Kanse SM, Mutch NJ, Degen JL, Booth NA. Activation of single-chain urokinase-type plasminogen activator by platelet-associated plasminogen: a mechanism for stimulation of fibrinolysis by platelets. J Thromb Haemost. 2010;8(6):1313-1322.

6. Whyte CS, Swieringa F, Mastenbroek TG, et al. Plasminogen associates with phosphatidylserine-exposing platelets and contributes to thrombus lysis under flow. Blood. 2015.

7. Collet JP, Park D, Lesty $C$, et al. Influence of fibrin network conformation and fibrin fiber diameter on fibrinolysis speed: dynamic and structural approaches by confocal microscopy. Arterioscler Thromb Vasc Biol. 2000;20(5):1354-1361.

8. Ono A, Westein $E, H$ siao $S$, et al. Identification of a fibrin-independent platelet contractile mechanism regulating primary hemostasis and thrombus growth. Blood. 2008;112(1):90-99.

9. Ginsberg MH, Du X, Plow EF. Inside-out integrin signalling. Curr Opin Cell Biol. 1992;4(5):766771.

10. Shattil SJ. Signaling through platelet integrin alpha IIb beta 3: inside-out, outside-in, and sideways. Thromb Haemost. 1999;82(2):318-325.

11. Knezevic I, Leisner TM, Lam SC. Direct binding of the platelet integrin alphallbbeta3 (GPIIbIIla) to talin. Evidence that interaction is mediated through the cytoplasmic domains of both alphallb and beta3. J Biol Chem. 1996;271(27):16416-16421.

12. Kasahara K, Kaneda M, Miki T, et al. Clot retraction is mediated by factor XIII-dependent fibrin-alphallbbeta3-myosin axis in platelet sphingomyelin-rich membrane rafts. Blood. 2013;122(19):3340-3348.

13. Sabovic M, Lijnen HR, Keber D, Collen D. Effect of retraction on the lysis of human clots with fibrin specific and non-fibrin specific plasminogen activators. Thromb Haemost. 1989;62(4):1083-1087.

14. Blinc A, Keber D, Lahajnar G, Zupancic I, Zorec-Karlovsek M, Demsar F. Magnetic resonance imaging of retracted and nonretracted blood clots during fibrinolysis in vitro. Haemostasis. 1992;22(4):195-201.

15. Aoki N. Clot retraction increases clot resistance to fibrinolysis by condensing alpha 2-plasmin inhibitor crosslinked to fibrin. Thromb Haemost. 1993;70(2):376.

16. Kunitada S, FitzGerald GA, Fitzgerald DJ. Inhibition of clot lysis and decreased binding of tissue-type plasminogen activator as a consequence of clot retraction. Blood. 1992;79(6):1420-1427.

17. Frojmovic MM, Milton JG. Human platelet size, shape, and related functions in health and disease. Physiol Rev. 1982;62(1):185-261.

18. Kieffer N, Guichard J, Farcet JP, Vainchenker W, Breton-Gorius J. Biosynthesis of major platelet proteins in human blood platelets. Eur J Biochem. 1987;164(1):189-195.

19. Leven RM, Schick PK, Budzynski AZ. Fibrinogen biosynthesis in isolated guinea pig megakaryocytes. Blood. 1985;65(2):501-504.

20. Chiu HC, Schick PK, Colman RW. Biosynthesis of factor V in isolated guinea pig megakaryocytes. J Clin Invest. 1985;75(2):339-346. 
21. Handagama PJ, George JN, Shuman MA, McEver RP, Bainton DF. Incorporation of a circulating protein into megakaryocyte and platelet granules. Proc Natl Acad Sci U S A. 1987;84(3):861-865.

22. Handagama PJ, Shuman MA, Bainton DF. Incorporation of intravenously injected albumin, immunoglobulin G, and fibrinogen in guinea pig megakaryocyte granules. J Clin Invest. 1989;84(1):73-82.

23. George JN, Saucerman S. Platelet $\lg G, \lg A$, IgM, and albumin: correlation of platelet and plasma concentrations in normal subjects and in patients with ITP or dysproteinemia. Blood. 1988;72(1):362-365.

24. Sehgal S, Storrie B. Evidence that differential packaging of the major platelet granule proteins von Willebrand factor and fibrinogen can support their differential release. $J$ Thromb Haemost. 2007;5(10):2009-2016.

25. Italiano JE, Jr., Richardson JL, Patel-Hett S, et al. Angiogenesis is regulated by a novel mechanism: pro- and antiangiogenic proteins are organized into separate platelet alpha granules and differentially released. Blood. 2008;111(3):1227-1233.

26. Harrison $\mathrm{P}$, Wilbourn B, Debili N, et al. Uptake of plasma fibrinogen into the alpha granules of human megakaryocytes and platelets. J Clin Invest. 1989;84(4):1320-1324.

27. Nachman RL, Marcus AJ, Zucker-Franklin D. Immunologic studies of proteins associated with subcellular fractions of normal human platelets. J Lab Clin Med. 1967;69(4):651-658.

28. James HL, Ganguly P, Jackson CW. Characterization and origin of fibrinogen in blood platelets. A review with recent data. Thromb Haemost. 1977;38(4):939-954.

29. Lopaciuk S, Lovette KM, McDonagh J, Chuang HY, McDonagh. Subcellular distribution of fibrinogen and factor XIII in human blood platelets. Thromb Res. 1976;8(4):453-465.

30. Kaplan KL, Broekman MJ, Chernoff A, Lesznik GR, Drillings M. Platelet alpha-granule proteins: studies on release and subcellular localization. Blood. 1979;53(4):604-618.

31. Karpatkin M, Howard L, Karpatkin S. Studies of the origin of platelet-associated fibrinogen. J Lab Clin Med. 1984;104(2):223-237.

32. Disdier M, Legrand C, Bouillot C, Dubernard V, Pidard D, Nurden AT. Quantitation of platelet fibrinogen and thrombospondin in Glanzmann's thrombasthenia by electroimmunoassay. Thromb Res. 1989;53(6):521-533.

33. George JN, Caen JP, Nurden AT. Glanzmann's thrombasthenia: the spectrum of clinical disease. Blood. 1990;75(7):1383-1395.

34. Cramer EM, Debili N, Martin JF, et al. Uncoordinated expression of fibrinogen compared with thrombospondin and von Willebrand factor in maturing human megakaryocytes. Blood. 1989;73(5):1123-1129.

35. Handagama P, Scarborough RM, Shuman MA, Bainton DF. Endocytosis of fibrinogen into megakaryocyte and platelet alpha-granules is mediated by alpha Illb beta 3 (glycoprotein IlbIIla). Blood. 1993;82(1):135-138.

36. Coller BS, Seligsohn U, West SM, Scudder LE, Norton KJ. Platelet fibrinogen and vitronectin in Glanzmann thrombasthenia: evidence consistent with specific roles for glycoprotein IIb/IIIA and alpha $v$ beta 3 integrins in platelet protein trafficking. Blood. 1991;78(10):2603-2610.

37. Maynard DM, Heijnen HF, Horne MK, White JG, Gahl WA. Proteomic analysis of platelet alpha-granules using mass spectrometry. J Thromb Haemost. 2007;5(9):1945-1955.

38. Veljkovic DK, Rivard GE, Diamandis M, Blavignac J, Cramer-Borde EM, Hayward CP. Increased expression of urokinase plasminogen activator in Quebec platelet disorder is linked to megakaryocyte differentiation. Blood. 2009;113(7):1535-1542.

39. Coppinger JA, Cagney G, Toomey S, et al. Characterization of the proteins released from activated platelets leads to localization of novel platelet proteins in human atherosclerotic lesions. Blood. 2004;103(6):2096-2104.

40. Robbins KC, Bernabe $P$, Arzadon L, Summaria L. NH2-terminal sequences of mammalian plasminogens and plasmin S-carboxymethyl heavy $(A)$ and light $(B)$ chain derivatives. A re- 
evaluation of the mechanism of activation of plasminogen. J Biol Chem. 1973;248(20):72427246.

41. Robbins KC, Summaria L, Hsieh B, Shah RJ. The peptide chains of human plasmin. Mechanism of activation of human plasminogen to plasmin. J Biol Chem. 1967;242(10):2333-2342.

42. Jang IK, Gold HK, Ziskind AA, et al. Differential sensitivity of erythrocyte-rich and platelet-rich arterial thrombi to lysis with recombinant tissue-type plasminogen activator. A possible explanation for resistance to coronary thrombolysis. Circulation. 1989;79(4):920-928.

43. Tomkins AJ, Schleicher N, Murtha L, et al. Platelet rich clots are resistant to lysis by thrombolytic therapy in a rat model of embolic stroke. Exp Trans/ Stroke Med. 2015;7:2.

44. Brogren $\mathrm{H}$, Karlsson L, Andersson M, Wang L, Erlinge D, Jern S. Platelets synthesize large amounts of active plasminogen activator inhibitor 1. Blood. 2004;104(13):3943-3948.

45. Brogren H, Wallmark K, Deinum J, Karlsson L, Jern S. Platelets retain high levels of active plasminogen activator inhibitor 1. PLoS One. 2011;6(11):e26762.

46. Declerck PJ, Alessi MC, Verstreken M, Kruithof EK, Juhan-Vague I, Collen D. Measurement of plasminogen activator inhibitor 1 in biologic fluids with a murine monoclonal antibody-based enzyme-linked immunosorbent assay. Blood. 1988;71(1):220-225.

47. Robbie LA, Young SP, Bennett B, Booth NA. Thrombi formed in a Chandler loop mimic human arterial thrombi in structure and RAI-1 content and distribution. Thromb Haemost. 1997;77(3):510-515.

48. Booth NA, Robbie LA, Croll AM, Bennett B. Lysis of platelet-rich thrombi: the role of PAI-1. Ann N Y Acad Sci. 1992;667:70-80.

49. Robbie LA, Bennett B, Croll AM, Brown PA, Booth NA. Proteins of the fibrinolytic system in human thrombi. Thromb Haemost. 1996;75(1):127-133.

50. Plow EF, Collen D. The presence and release of alpha 2-antiplasmin from human platelets. Blood. 1981;58(6):1069-1074.

51. Gogstad GO, Stormorken H, Solum NO. Platelet alpha 2-antiplasmin is located in the platelet alpha-granules. Thromb Res. 1983;31(2):387-390.

52. Reed GL, Matsueda GR, Haber E. Platelet factor XIII increases the fibrinolytic resistance of platelet-rich clots by accelerating the crosslinking of alpha 2-antiplasmin to fibrin. Thromb Haemost. 1992;68(3):315-320.

53. Reed GL, Matsueda GR, Haber E. Fibrin-fibrin and alpha 2-antiplasmin-fibrin cross-linking by platelet factor XIII increases the resistance of platelet clots to fibrinolysis. Trans Assoc Am Physicians. 1991;104:21-28.

54. Mitchell JL, Lionikiene AS, Fraser SR, Whyte CS, Booth NA, Mutch NJ. Functional factor XIII-A is exposed on the stimulated platelet surface. Blood. 2014.

55. Bajzar L, Morser J, Nesheim M. TAFI, or plasma procarboxypeptidase B, couples the coagulation and fibrinolytic cascades through the thrombin-thrombomodulin complex. J Biol Chem. 1996;271(28):16603-16608.

56. Mao SS, Cooper CM, Wood T, Shafer JA, Gardell SJ. Characterization of plasmin-mediated activation of plasma procarboxypeptidase B. Modulation by glycosaminoglycans. J Biol Chem. 1999;274(49):35046-35052.

57. Nesheim M. Fibrinolysis and the plasma carboxypeptidase. Curr Opin Hematol. 1998;5(5):309-313.

58. Schadinger SL, Lin JH, Garand M, Boffa MB. Secretion and antifibrinolytic function of thrombin-activatable fibrinolysis inhibitor from human platelets. J Thromb Haemost. 2010;8(11):2523-2529.

59. Leung LL, Harpel PC, Nachman RL. Platelet histidine-rich glycoprotein. Methods Enzymol. 1989;169:268-276.

60. Leung LL, Harpel PC, Nachman RL, Rabellino EM. Histidine-rich glycoprotein is present in human platelets and is released following thrombin stimulation. Blood. 1983;62(5):10161021. 
61. Lerch PG, Nydegger UE, Kuyas C, Haeberli A. Histidine-rich glycoprotein binding to activated human platelets. Br J Haematol. 1988;70(2):219-224.

62. Tsuchida-Straeten N, Ensslen S, Schafer C, et al. Enhanced blood coagulation and fibrinolysis in mice lacking histidine-rich glycoprotein (HRG). J Thromb Haemost. 2005;3(5):865-872.

63. Leung LL. Interaction of histidine-rich glycoprotein with fibrinogen and fibrin. J Clin Invest. 1986;77(4):1305-1311.

64. Vu TT, Stafford AR, Leslie BA, Kim PY, Fredenburgh JC, Weitz JI. Histidine-rich glycoprotein binds fibrin(ogen) with high affinity and competes with thrombin for binding to the gamma'chain. J Biol Chem. 2011;286(35):30314-30323.

65. Lijnen HR, Hoylaerts M, Collen D. Isolation and characterization of a human plasma protein with affinity for the lysine binding sites in plasminogen. Role in the regulation of fibrinolysis and identification as histidine-rich glycoprotein. J Biol Chem. 1980;255(21):10214-10222.

66. Jones AL, Hulett MD, Altin JG, Hogg P, Parish CR. Plasminogen is tethered with high affinity to the cell surface by the plasma protein, histidine-rich glycoprotein. J Biol Chem. 2004;279(37):38267-38276.

67. Schmaier AH, Smith PM, Colman RW. Platelet C1- inhibitor. A secreted alpha-granule protein. J Clin Invest. 1985;75(1):242-250.

68. Booth NA, Anderson JA, Bennett B. Plasminogen activators in alcoholic cirrhosis: demonstration of increased tissue type and urokinase type activator. J Clin Pathol. 1984;37(7):772-777.

69. Booth NA, Walker E, Maughan R, Bennett B. Plasminogen activator in normal subjects after exercise and venous occlusion: t-PA circulates as complexes with C1-inhibitor and PAI-1. Blood. 1987;69(6):1600-1604.

70. Huisman LG, van Griensven JM, Kluft C. On the role of C1-inhibitor as inhibitor of tissue-type plasminogen activator in human plasma. Thromb Haemost. 1995;73(3):466-471.

71. Gurewich V, Pannell R, Simmons-Byrd A, Sarmientos P, Liu JN, Badylak SF. Thrombolysis vs. bleeding from hemostatic sites by a prourokinase mutant compared with tissue plasminogen activator. J Thromb Haemost. 2006;4(7):1559-1565.

72. Gurewich V. Fibrinolytic Mechanisms of tPA, prouPA, Mutant prouPA and Their Implications for Therapeutic Thrombolysis. Cardiovascular Engineering and Technology. 2013;4(4):328338.

73. Bouton MC, Boulaftali Y, Richard B, Arocas V, Michel JB, Jandrot-Perrus M. Emerging role of serpinE2/protease nexin-1 in hemostasis and vascular biology. Blood. 2012;119(11):24522457.

74. Gronke RS, Knauer DJ, Veeraraghavan S, Baker JB. A form of protease nexin I is expressed on the platelet surface during platelet activation. Blood. 1989;73(2):472-478.

75. Mansilla S, Boulaftali $Y$, Venisse L, et al. Macrophages and platelets are the major source of protease nexin-1 in human atherosclerotic plaque. Arterioscler Thromb Vasc Biol. 2008;28(10):1844-1850.

76. Boulaftali Y, Adam F, Venisse L, et al. Anticoagulant and antithrombotic properties of platelet protease nexin-1. Blood. 2010;115(1):97-106.

77. Boulaftali Y, Ho-Tin-Noe B, Pena A, et al. Platelet protease nexin-1, a serpin that strongly influences fibrinolysis and thrombolysis. Circulation. 2011;123(12):1326-1334.

78. Kornberg A, Rao NN, Ault-Riche D. Inorganic polyphosphate: a molecule of many functions. Annu Rev Biochem. 1999;68:89-125.

79. Ruiz FA, Lea CR, Oldfield E, Docampo R. Human platelet dense granules contain polyphosphate and are similar to acidocalcisomes of bacteria and unicellular eukaryotes. $J$ Biol Chem. 2004;279(43):44250-44257.

80. Muller F, Mutch NJ, Schenk WA, et al. Platelet polyphosphates are proinflammatory and procoagulant mediators in vivo. Cell. 2009;139(6):1143-1156. 
81. Smith SA, Mutch NJ, Baskar D, Rohloff P, Docampo R, Morrissey JH. Polyphosphate modulates blood coagulation and fibrinolysis. Proc Natl Acad Sci U S A. 2006;103(4):903-908.

82. Smith SA, Choi SH, Davis-Harrison R, et al. Polyphosphate exerts differential effects on blood clotting, depending on polymer size. Blood. 2010;116(20):4353-4359.

83. Mutch NJ, Engel R, Uitte de Willige S, Philippou H, Ariens RA. Polyphosphate modifies the fibrin network and down-regulates fibrinolysis by attenuating binding of tPA and plasminogen to fibrin. Blood. 2010;115(19):3980-3988.

84. Engel R, Brain CM, Paget J, Lionikiene AS, Mutch NJ. Single-chain factor XII exhibits activity when complexed to polyphosphate. J Thromb Haemost. 2014;12(9):1513-1522.

85. Nickel KF, Spronk HM, Mutch NJ, Renne T. Time-dependent degradation and tissue factor addition mask the ability of platelet polyphosphates in activating factor XII-mediated coagulation. Blood. 2013;122(23):3847-3849.

86. Tans G, Rosing J. Structural and functional characterization of factor XII. Semin Thromb Hemost. 1987;13(1):1-14.

87. Goldsmith GH, Jr., Saito $H$, Ratnoff OS. The activation of plasminogen by Hageman factor (Factor XII) and Hageman factor fragments. J Clin Invest. 1978;62(1):54-60.

88. Konings J, Hoving LR, Ariens RS, et al. The role of activated coagulation factor XII in overall clot stability and fibrinolysis. Thromb Res. 2015;136(2):474-480.

89. Pisano JJ, Finlayson JS, Peyton MP. [Cross-link in fibrin polymerized by factor 13: epsilon(gamma-glutamyl)lysine]. Science. 1968;160(3830):892-893.

90. Pisano JJ, Finlayson JS, Peyton MP. Chemical and enzymic detection of protein cross-links. Measurement of epsilon-(gamma-glutamyl)lysine in fibrin polymerized by factor XIII. Biochemistry. 1969;8(3):871-876.

91. Buluk K. [An unknown action of blood platelets; preliminary communication]. Pol Tyg Lek (Wars). 1955;10(6):191.

92. Luscher EF. [Fibrin-stabilizing factor from thrombocytes]. Schweiz Med Wochenschr. 1957;87(39-40):1220-1221.

93. Kiesselbach TH, Wagner RH. Fibrin-stabilizing factor: a thrombin-labile platelet protein. Am J Physiol. 1966;211(6):1472-1476.

94. Katona EE, Ajzner E, Toth K, Karpati L, Muszbek L. Enzyme-linked immunosorbent assay for the determination of blood coagulation factor XIII A-subunit in plasma and in cell lysates. $J$ Immunol Methods. 2001;258(1-2):127-135.

95. Sixma JJ, van den Berg A, Schiphorst M, Geuze HJ, McDonagh J. Immunocytochemical localization of albumin and factor XIII in thin cryo sections of human blood platelets. Thromb Haemost. 1984;51(3):388-391.

96. Marx G, Korner G, Mou X, Gorodetsky R. Packaging zinc, fibrinogen, and factor XIII in platelet alpha-granules. J Cell Physiol. 1993;156(3):437-442.

97. Joist JH, Niewiarowski S. Retention of platelet fibrin stabilizing factor during the platelet release reaction and clot retraction. Thromb Diath Haemorrh. 1973;29(3):679-683.

98. Kaetsu $H$, Hashiguchi $T$, Foster D, Ichinose A. Expression and release of the a and $b$ subunits for human coagulation factor XIII in baby hamster kidney (BHK) cells. J Biochem. 1996;119(5):961-969.

99. Cordell PA, Kile BT, Standeven KF, Josefsson EC, Pease RJ, Grant PJ. Association of coagulation factor XIII-A with Golgi proteins within monocyte-macrophages: implications for subcellular trafficking and secretion. Blood. 2010;115(13):2674-2681.

100. Sakata Y, Aoki N. Cross-linking of alpha 2-plasmin inhibitor to fibrin by fibrin-stabilizing factor. J Clin Invest. 1980;65(2):290-297.

101. Valnickova Z, Enghild JJ. Human procarboxypeptidase U, or thrombin-activable fibrinolysis inhibitor, is a substrate for transglutaminases. Evidence for transglutaminase-catalyzed cross-linking to fibrin. J Biol Chem. 1998;273(42):27220-27224. 
102. Ritchie $\mathrm{H}$, Robbie LA, Kinghorn S, Exley R, Booth NA. Monocyte plasminogen activator inhibitor 2 (PAI-2) inhibits u-PA-mediated fibrin clot lysis and is cross-linked to fibrin. Thromb Haemost. 1999;81(1):96-103.

103. Fraser SR, Booth NA, Mutch NJ. The antifibrinolytic function of factor XIII is exclusively expressed through alpha(2)-antiplasmin cross-linking. Blood. 2011;117(23):6371-6374.

104. Mutch NJ, Koikkalainen JS, Fraser SR, et al. Model thrombi formed under flow reveal the role of factor XIII-mediated cross-linking in resistance to fibrinolysis. J Thromb Haemost. 2010;8(9):2017-2024.

105. Hevessy Z, Haramura G, Boda Z, Udvardy M, Muszbek L. Promotion of the crosslinking of fibrin and alpha 2-antiplasmin by platelets. Thromb Haemost. 1996;75(1):161-167.

106. Francis CW, Marder VJ. Rapid formation of large molecular weight alpha-polymers in crosslinked fibrin induced by high factor XIII concentrations. Role of platelet factor XIII. J Clin Invest. 1987;80(5):1459-1465.

107. Rubens FD, Perry DW, Hatton MW, Bishop PD, Packham MA, Kinlough-Rathbone RL. Platelet accumulation on fibrin-coated polyethylene: role of platelet activation and factor XIII. Thromb Haemost. 1995;73(5):850-856.

108. Chang JY, Monroe DM, Oliver JA, Roberts HR. TFPIbeta, a second product from the mouse tissue factor pathway inhibitor (TFPI) gene. Thromb Haemost. 1999;81(1):45-49.

109. Maroney SA, Ferrel JP, Collins ML, Mast AE. Tissue factor pathway inhibitor-gamma is an active alternatively spliced form of tissue factor pathway inhibitor present in mice but not in humans. J Thromb Haemost. 2008;6(8):1344-1351.

110. Maroney SA, Haberichter SL, Friese $P$, et al. Active tissue factor pathway inhibitor is expressed on the surface of coated platelets. Blood. 2007;109(5):1931-1937.

111. Maroney SA, Cooley BC, Ferrel JP, Bonesho CE, Mast AE. Murine hematopoietic cell tissue factor pathway inhibitor limits thrombus growth. Arterioscler Thromb Vasc Biol. 2011;31(4):821-826.

112. Vadivel K, Ponnuraj SM, Kumar Y, et al. Platelets contain tissue factor pathway inhibitor-2 derived from megakaryocytes and inhibits fibrinolysis. J Biol Chem. 2014;289(45):3164731661.

113. Grau E, Moroz LA. Fibrinolytic activity of normal human blood monocytes. Thromb Res. 1989;53(2):145-162.

114. Manchanda N, Schwartz BS. Lipopolysaccharide-induced modulation of human monocyte urokinase production and activity. J Immunol. 1990;145(12):4174-4180.

115. Larsson LI, Skriver L, Nielsen LS, Grondahl-Hansen J, Kristensen P, Dano K. Distribution of urokinase-type plasminogen activator immunoreactivity in the mouse. $J$ Cell Biol. 1984;98(3):894-903.

116. Lijnen HR, Van Hoef B, Collen D. Activation with plasmin of two-chain urokinase-type plasminogen activator derived from single-chain urokinase-type plasminogen activator by treatment with thrombin. Eur J Biochem. 1987;169(2):359-364.

117. Diamandis M, Veljkovic DK, Maurer-Spurej E, Rivard GE, Hayward CP. Quebec platelet disorder: features, pathogenesis and treatment. Blood Coagul Fibrinolysis. 2008;19(2):109119.

118. Hayward CP, Cramer EM, Kane WH, et al. Studies of a second family with the Quebec platelet disorder: evidence that the degradation of the alpha-granule membrane and its soluble contents are not secondary to a defect in targeting proteins to alpha-granules. Blood. 1997;89(4):1243-1253.

119. Gurewich V, Emmons F, Pannell R. Spontaneous clot lysis in whole human plasma by endogenous tissue type and urokinase type plasminogen activators: Demonstration of a promoting effect by t-PA and by platelets on urokinase. Fibrinolysis. 1988;2(3):143-149.

120. Park S, Harker LA, Marzec UM, Levin EG. Demonstration of single chain urokinase-type plasminogen activator on human platelet membrane. Blood. 1989;73(6):1421-1425. 
121. Jiang Y, Pannell R, Liu JN, Gurewich V. Evidence for a novel binding protein to urokinase-type plasminogen activator in platelet membranes. Blood. 1996;87(7):2775-2781.

122. Gurewich V, Johnstone M, Loza JP, Pannell R. Pro-urokinase and prekallikrein are both associated with platelets. Implications for the intrinsic pathway of fibrinolysis and for therapeutic thrombolysis. FEBS Lett. 1993;318(3):317-321.

123. Lenich C, Liu JN, Gurewich V. Thrombin stimulation of platelets induces plasminogen activation mediated by endogenous urokinase-type plasminogen activator. Blood. 1997;90(9):3579-3586.

124. Levin EG, Loskutoff DJ. Cultured bovine endothelial cells produce both urokinase and tissuetype plasminogen activators. J Cell Biol. 1982;94(3):631-636.

125. Jeanneau $C$, Sultan $Y$. Tissue plasminogen activator in human megakaryocytes and platelets: immunocytochemical localization, immunoblotting and zymographic analysis. Thromb Haemost. 1988;59(3):529-534.

126. Rijken DC, Hoylaerts M, Collen D. Fibrinolytic properties of one-chain and two-chain human extrinsic (tissue-type) plasminogen activator. J Biol Chem. 1982;257(6):2920-2925.

127. Hoylaerts M, Rijken DC, Lijnen HR, Collen D. Kinetics of the activation of plasminogen by human tissue plasminogen activator. Role of fibrin. J Biol Chem. 1982;257(6):2912-2919.

128. Gao SW, Morser J, McLean K, Shuman MA. Differential effect of platelets on plasminogen activation by tissue plasminogen activator, urokinase, and streptokinase. Thromb Res. 1990;58(4):421-433.

129. Vaughan DE, Mendelsohn ME, Declerck PJ, Van Houtte E, Collen D, Loscalzo J. Characterization of the binding of human tissue-type plasminogen activator to platelets. J Biol Chem. 1989;264(27):15869-15874.

130. Deguchi K, Shirakawa S. Plasminogen activation by tissue plasminogen activator in the presence of platelets. Thromb Res Suppl. 1988;8:65-72.

131. Hajjar KA, Krishnan S. Annexin II: a mediator of the plasmin/plasminogen activator system. Trends Cardiovasc Med. 1999;9(5):128-138.

132. Collet JP, Montalescot G, Lesty C, Weisel JW. A structural and dynamic investigation of the facilitating effect of glycoprotein IIb/IIla inhibitors in dissolving platelet-rich clots. Circ Res. 2002;90(4):428-434.

133. Alberio L, Safa O, Clemetson KJ, Esmon CT, Dale GL. Surface expression and functional characterization of alpha-granule factor $\mathrm{V}$ in human platelets: effects of ionophore A23187, thrombin, collagen, and convulxin. Blood. 2000;95(5):1694-1702.

134. Kulkarni S, Jackson SP. Platelet factor XIII and calpain negatively regulate integrin alphallbbeta3 adhesive function and thrombus growth. J Biol Chem. 2004;279(29):3069730706.

135. Kempton CL, Hoffman M, Roberts HR, Monroe DM. Platelet heterogeneity: variation in coagulation complexes on platelet subpopulations. Arterioscler Thromb Vasc Biol. 2005;25(4):861-866.

136. Heemskerk JW, Vuist WM, Feijge MA, Reutelingsperger CP, Lindhout T. Collagen but not fibrinogen surfaces induce bleb formation, exposure of phosphatidylserine, and procoagulant activity of adherent platelets: evidence for regulation by protein tyrosine kinase-dependent Ca2+ responses. Blood. 1997;90(7):2615-2625.

137. Bevers EM, Comfurius P, van Rijn JL, Hemker HC, Zwaal RF. Generation of prothrombinconverting activity and the exposure of phosphatidylserine at the outer surface of platelets. Eur J Biochem. 1982;122(2):429-436.

138. Munnix IC, Kuijpers MJ, Auger J, et al. Segregation of platelet aggregatory and procoagulant microdomains in thrombus formation: regulation by transient integrin activation.

Arterioscler Thromb Vasc Biol. 2007;27(11):2484-2490. 
139. Collet JP, Montalescot G, Lesty C, et al. Disaggregation of in vitro preformed platelet-rich clots by abciximab increases fibrin exposure and promotes fibrinolysis. Arterioscler Thromb Vasc Biol. 2001;21(1):142-148.

140. Siljander P, Farndale RW, Feijge MA, et al. Platelet adhesion enhances the glycoprotein VIdependent procoagulant response: Involvement of p38 MAP kinase and calpain. Arterioscler Thromb Vasc Biol. 2001;21(4):618-627.

141. Berny MA, Munnix IC, Auger JM, et al. Spatial distribution of factor Xa, thrombin, and fibrin(ogen) on thrombi at venous shear. PLoS One. 2010;5(4):e10415.

142. Cosemans JM, Schols SE, Stefanini L, et al. Key role of glycoprotein Ib/V/IX and von Willebrand factor in platelet activation-dependent fibrin formation at low shear flow. Blood. 2011;117(2):651-660.

143. Mattheij NJ, Swieringa F, Mastenbroek TG, et al. Coated platelets function in plateletdependent fibrin formation via integrin alphallbbeta3 and transglutaminase factor XIII. Haematologica. 2015.

144. Shi J, Pipe SW, Rasmussen JT, Heegaard CW, Gilbert GE. Lactadherin blocks thrombosis and hemostasis in vivo: correlation with platelet phosphatidylserine exposure. J Thromb Haemost. 2008;6(7):1167-1174.

145. Kuijpers MJ, Munnix IC, Cosemans JM, et al. Key role of platelet procoagulant activity in tissue factor-and collagen-dependent thrombus formation in arterioles and venules in vivo differential sensitivity to thrombin inhibition. Microcirculation. 2008;15(4):269-282.

146. Dale GL, Friese P, Batar P, et al. Stimulated platelets use serotonin to enhance their retention of procoagulant proteins on the cell surface. Nature. 2002;415(6868):175-179.

147. Dale GL. Coated-platelets: an emerging component of the procoagulant response. J Thromb Haemost. 2005;3(10):2185-2192.

148. Szasz R, Dale GL. Thrombospondin and fibrinogen bind serotonin-derivatized proteins on COAT-platelets. Blood. 2002;100(8):2827-2831.

149. Heemskerk JW, Mattheij NJ, Cosemans JM. Platelet-based coagulation: different populations, different functions. J Thromb Haemost. 2013;11(1):2-16.

150. Prodan $\mathrm{Cl}$, Dale GL. Coated-platelets in ischemic stroke - potential insight into the etiology of stroke subtypes. Int J Stroke. 2008;3(4):249-250.

151. Brooks MB, Catalfamo JL, Friese P, Dale GL. Scott syndrome dogs have impaired coatedplatelet formation and calcein-release but normal mitochondrial depolarization. J Thromb Haemost. 2007;5(9):1972-1974.

152. Abaeva AA, Canault M, Kotova YN, et al. Procoagulant platelets form an alpha-granule protein-covered "cap" on their surface that promotes their attachment to aggregates. J Biol Chem. 2013;288(41):29621-29632.

153. Podoplelova NA, Sveshnikova AN, Kotova YN, et al. Blood coagulation factors bound to procoagulant platelets are concentrated in their cap structures to promote clotting. Blood. 2016.

154. Mattheij NJ, Swieringa F, Mastenbroek TG, et al. Coated platelets function in plateletdependent fibrin formation via integrin alphallbbeta3 and transglutaminase factor XIII. Haematologica. 2016;101(4):427-436.

155. Mattheij NJ, Gilio K, van Kruchten R, et al. Dual mechanism of integrin alphallbbeta3 closure in procoagulant platelets. J Biol Chem. 2013;288(19):13325-13336.

156. Miles LA, Ginsberg MH, White JG, Plow EF. Plasminogen interacts with human platelets through two distinct mechanisms. J Clin Invest. 1986;77(6):2001-2009.

157. Stalker TJ, Traxler EA, Wu J, et al. Hierarchical organization in the hemostatic response and its relationship to the platelet-signaling network. Blood. 2013;121(10):1875-1885.

158. Stalker TJ, Welsh JD, Tomaiuolo M, et al. A systems approach to hemostasis: 3 . Thrombus consolidation regulates intrathrombus solute transport and local thrombin activity. Blood. 2014;124(11):1824-1831. 
159. van Gestel MA, Heemskerk JW, Slaaf DW, et al. Real-time detection of activation patterns in individual platelets during thromboembolism in vivo: differences between thrombus growth and embolus formation. J Vasc Res. 2002;39(6):534-543.

160. Niiya K, Hodson E, Bader R, et al. Increased surface expression of the membrane glycoprotein Ilb/IIla complex induced by platelet activation. Relationship to the binding of fibrinogen and platelet aggregation. Blood. 1987;70(2):475-483.

161. Mazzucato M, Pradella P, Cozzi MR, De Marco L, Ruggeri ZM. Sequential cytoplasmic calcium signals in a 2-stage platelet activation process induced by the glycoprotein Ibalpha mechanoreceptor. Blood. 2002;100(8):2793-2800.

162. Miles LA, Plow EF. Binding and activation of plasminogen on the platelet surface. J Biol Chem. 1985;260(7):4303-4311.

163. Adelman B, Michelson AD, Loscalzo J, Greenberg J, Handin RI. Plasmin effect on platelet glycoprotein Ib-von Willebrand factor interactions. Blood. 1985;65(1):32-40.

164. Plow EF, Doeuvre L, Das R. So many plasminogen receptors: why? J Biomed Biotechnol. 2012;2012:141806.

165. Potter van Loon BJ, Rijken DC, Brommer EJ, van der Maas AP. The amount of plasminogen, tissue-type plasminogen activator and plasminogen activator inhibitor type 1 in human thrombi and the relation to ex-vivo lysibility. Thromb Haemost. 1992;67(1):101-105.

166. Dejouvencel T, Doeuvre L, Lacroix R, et al. Fibrinolytic cross-talk: a new mechanism for plasmin formation. Blood. 2010;115(10):2048-2056.

167. Stricker RB, Wong D, Shiu DT, Reyes PT, Shuman MA. Activation of plasminogen by tissue plasminogen activator on normal and thrombasthenic platelets: effects on surface proteins and platelet aggregation. Blood. 1986;68(1):275-280.

168. Ouimet $\mathrm{H}$, Freedman JE, Loscalzo J. Kinetics and mechanism of platelet-surface plasminogen activation by tissue-type plasminogen activator. Biochemistry. 1994;33(10):2970-2976.

169. Loscalzo J, Pasche B, Ouimet H, Freedman JE. Platelets and plasminogen activation. Thromb Haemost. 1995;74(1):291-293.

170. Plow EF, Freaney DE, Plescia J, Miles LA. The plasminogen system and cell surfaces: evidence for plasminogen and urokinase receptors on the same cell type. J Cell Biol. 1986;103(6 Pt 1):2411-2420.

171. Hall SW, Humphries JE, Gonias SL. Inhibition of cell surface receptor-bound plasmin by alpha 2-antiplasmin and alpha 2-macroglobulin. J Biol Chem. 1991;266(19):12329-12336.

172. Zhu Y, Carmeliet $P$, Fay WP. Plasminogen activator inhibitor-1 is a major determinant of arterial thrombolysis resistance. Circulation. 1999;99(23):3050-3055.

173. Podor TJ, Peterson CB, Lawrence DA, et al. Type 1 plasminogen activator inhibitor binds to fibrin via vitronectin. J Biol Chem. 2000;275(26):19788-19794.

174. Preissner KT, Grulich-Henn J, Ehrlich HJ, et al. Structural requirements for the extracellular interaction of plasminogen activator inhibitor 1 with endothelial cell matrix-associated vitronectin. J Biol Chem. 1990;265(30):18490-18498.

175. Lawrence DA, Palaniappan S, Stefansson S, et al. Characterization of the binding of different conformational forms of plasminogen activator inhibitor-1 to vitronectin. Implications for the regulation of pericellular proteolysis. J Biol Chem. 1997;272(12):7676-7680.

176. Braaten JV, Handt S, Jerome WG, Kirkpatrick J, Lewis JC, Hantgan RR. Regulation of fibrinolysis by platelet-released plasminogen activator inhibitor 1: light scattering and ultrastructural examination of lysis of a model platelet-fibrin thrombus. Blood. 1993;81(5):1290-1299.

177. Suzuki K, Nishioka J, Hayashi T, Kosaka Y. Functionally active thrombomodulin is present in human platelets. J Biochem. 1988;104(4):628-632.

178. Vercauteren E, Mutch NJ, Declerck PJ, Gils A. Plasmin and the thrombin-thrombomodulin complex both contribute to thrombin-activatable fibrinolysis inhibitor activation in whole blood model thrombi. J Thromb Haemost. 2013;11(1):190-192. 
179. Carrieri C, Galasso R, Semeraro F, Ammollo CT, Semeraro N, Colucci M. The role of thrombin activatable fibrinolysis inhibitor and factor $\mathrm{XI}$ in platelet-mediated fibrinolysis resistance: a thromboelastographic study in whole blood. J Thromb Haemost. 2011;9(1):154-162.

180. Wyseure T, Rubio M, Denorme F, et al. Innovative thrombolytic strategy using a heterodimer diabody against TAFI and PAI-1 in mouse models of thrombosis and stroke. Blood. 2015;125(8):1325-1332.

181. Denorme F, Wyseure T, Peeters M, et al. Inhibition of Thrombin-Activatable Fibrinolysis Inhibitor and Plasminogen Activator Inhibitor-1 Reduces Ischemic Brain Damage in Mice. Stroke. 2016;47(9):2419-2422.

182. Wang X, Palasubramaniam J, Gkanatsas Y, et al. Towards effective and safe thrombolysis and thromboprophylaxis: preclinical testing of a novel antibody-targeted recombinant plasminogen activator directed against activated platelets. Circ Res. 2014;114(7):1083-1093.

183. Nachman RL. Immunologic Studies of Platelet Protein. Blood. 1965;25:703-711. 


\section{FIGURE LEGENDS}

\section{Figure 1: Cartoon representation of platelet structure.}

A basic schematic of platelet structure indicating several membrane receptors and their ligands, including $\alpha_{\| 1} \beta_{3}$ and its ligand fibrinogen and the PAR1 and PAR4 receptors with their ligand, thrombin. The actin cytoskeleton is attached to the inner leaflet of the platelet membrane and joins to the cytoplasmic tails of the $\alpha_{\| 1 b} \beta_{3}$ receptor via clot retraction mediators such as talin and vinculin. Platelets contain a number of intracellular granules including $\alpha$-granules which contain a plethora of hemostatic proteins and dense-granules which house mediators such as $\mathrm{Ca}^{2+}$, serotonin and polyphosphate. Glycoprotein VI (GPVI), IX (GPIX), 1b $\alpha$ (GP1b $\alpha$ ?, $1 b \beta$ (GP1b $\beta$ ) protease-activated receptor 1 (PAR1) or 4 (PAR4), adenosine diphosphate (ADP), ADP receptors ( $P 2 \mathrm{Y}_{1}$ and $\left.P 2 \mathrm{Y}_{12}\right)$, von Willebrand factor(VWF) and plasminogen activator inhibitor (PAI-1).

Figure 2: Cartoon representation of fibrinolytic factors bound PS-exposing and PS-negative platelet surfaces and platelet-anchored fibrin

A number of fibrinolytic mediators bind to the activated platelet surface and the surrounding fibrin network. This diagram represents the pro- (plasminogen, FXIla) and antifibrinolytic factors (FXIII-A; PAI-1, C1-Inhibitor) bound to activated spread PS-negative (A) or balloon-shaped procoagulant PS-exposing platelet surface (B) and platelet-anchored fibrin (blue). Histidine rich glycoprotein (HRG), C1 inhibitor ( $\mathrm{C} 1 \mathrm{INH})$, plasminogen (plgn) and polyphosphate (polyP).

Figure 3 - Localization of fibrinolytic proteins in PS-exposing and PS-negative platelets. Washed platelets $\left(0.5 \times 10^{8} / \mathrm{ml}\right)$ were adhered to a collagen $(0.6 \mu \mathrm{g})+$ thrombin $(3 \mathrm{pmol})$ 
coated slide and stained using FITC-labeled anti-FXIII-A antibody, FITC-labeled activated $\alpha_{11 b} \beta_{3}$ (PAC-1) or anti-PAl-1 DyLight 488-labeled antibody. Alexa-fluor647 Annexin A5 (1/20 dilution) or Annexin A5-FITC (1/20 dilution) was used to detect phosphatidylserine (PS) where indicated. Alternativelly after 40 min incubation, plasminogen-DL633 (0.8 $\mu \mathrm{M})$ or fibrinogen-AF647 $(16.7 \mu \mathrm{g} / \mathrm{ml})$ were added. Shown are representative images $(\mathrm{n}=\geq 3$ experiments) of differential interference contrast (DIC) of FXIII, PAI-1 or PAC-1 expression and plasminogen or fibrinogen binding on balloon shaped PS-exposing platelets (left) or spread PS-negative platelets (right). Images were obtained with a Zeiss LSM710 confocal microscope with a $63 \times 1.40$ oil immersion objective and were analyzed using Zen 2012 software. Scale bar $=5 \mu \mathrm{m}$.

Figure 4 - Plasminogen localization within thrombi. Thrombi were formed by whole blood perfusion $\left(1000 \mathrm{~s}^{-1}\right)$ over a collagen/tissue factor-coated surface \pm hirudin $(3 \mu \mathrm{g} / \mathrm{ml})$. Platelets labeled with DiOC6 $(0.5 \mu \mathrm{g} / \mathrm{ml})$ or fibrinogen-OG488 $(75 \mu \mathrm{g} / \mathrm{ml})$ were included. Thrombi were perfused with plasminogen-DL-633 (0.8 $\mu \mathrm{M})$. Confocal z-stacks were recorded of labeled thrombi (16-bit images of 102431024 pixels; 1063106 mm; stack distance $0.5 \mathrm{~mm}$; 50 slices). Representative images and overlays of plasminogen (blue) and platelets (green), or fibrin(ogen) (red) taken from z-stacks at the base $(0 \mathrm{~mm})$, center (10 $\mathrm{mm}$ ), and top (20 $\mathrm{mm}$ ) of thrombi before (top panel) or after (bottom panel) visible fibrin formation. 


\begin{tabular}{|c|c|c|c|c|}
\hline Protein & $\begin{array}{l}\text { Concentration } \\
\text { (ng/109 platelets) }\end{array}$ & Primary location & Biosynthesis/uptake & References \\
\hline Fibrinogen & 52500 & $\alpha$-granules, cytoplasm & platelet \& megakaryocyte endocytosis & 28,183 \\
\hline Plasminogen & $?$ & $\alpha$-granules & $\begin{array}{c}\text { megakaryocytic (platelet?) } \\
\text { endocytosis }\end{array}$ & 37,38 \\
\hline PAI-1 & 670 & $\alpha$-granules & platelet biosynthesis & 2,44 \\
\hline$\alpha_{2} \mathrm{AP}$ & 62 & $\alpha$-granules & ? & 50 \\
\hline TAFI & 50 & $\alpha$-granules & megakaryocyte biosynthesis & 4,58 \\
\hline HRG & 371 & $\alpha$-granules & platelet \& megakaryocyte endocytosis & 59,60 \\
\hline C1 inhibitor & 620 & $\alpha$-granules & megakaryocyte biosynthesis & 3,67 \\
\hline PN-1 & b & $\alpha$-granules & megakaryocyte biosynthesis & 75,76 \\
\hline poly $\mathrm{P}^{\mathrm{a}}$ & 755 & dense granules & - & 79 \\
\hline FXIII-A & 60000 & cytoplasm & megakaryocyte biosynthesis & 94 \\
\hline TFPI & 22 & $\begin{array}{l}\text { ? (not thought to be } \alpha \text { - } \\
\text { granules or lysozymes) }\end{array}$ & megakaryocyte biosynthesis & 110,111 \\
\hline scuPA/uPA & 1.3 & membrane & Plasma derived & 117,122 \\
\hline tPA & $?$ & membrane & Plasma derived & 128,129 \\
\hline
\end{tabular}

Table 1 - Summary of fibrinolytic proteins detected in platelets. Unknown parameters are indicated by ?. ${ }^{a}$ polyphosphate is an inorganic biomolecule. ${ }^{b}$ the total $\mathrm{PN}-1$ concentration within platelets has not been reported but the amount released by $3 \times 10^{8}$ platelets $/ \mathrm{ml}$ is approximately $20 \mathrm{mmol} / \mathrm{L}^{73}$ Plasminogen activator-1 (PAI-1), alpha2 antiplasmin ( $\left.\alpha_{2} \mathrm{AP}\right)$, thrombin activatable fibrinolysis inhibitor (TAFI), histidine rich glycoprotein (HRG), protease nexin-1 (PN-1), polyphosphate (polyP), factor XIII-A (FXIII-A), tissue factor pathway inhibitor (TFPI), (single chain) urokinase plasminogen activator (scuPA/uPA) and tissue plasminogen activator (tPA). 
Figure 1

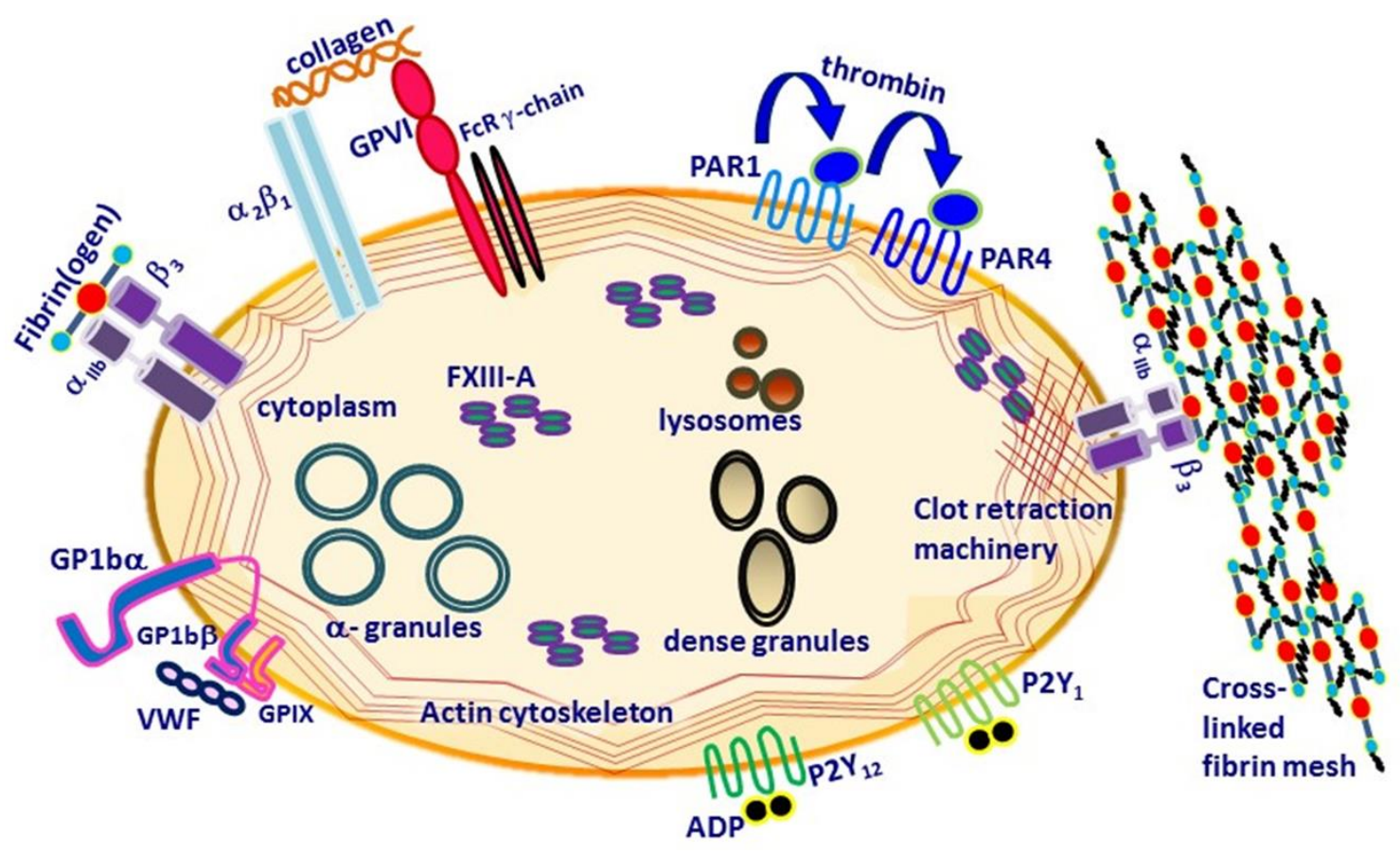


Figure 2A

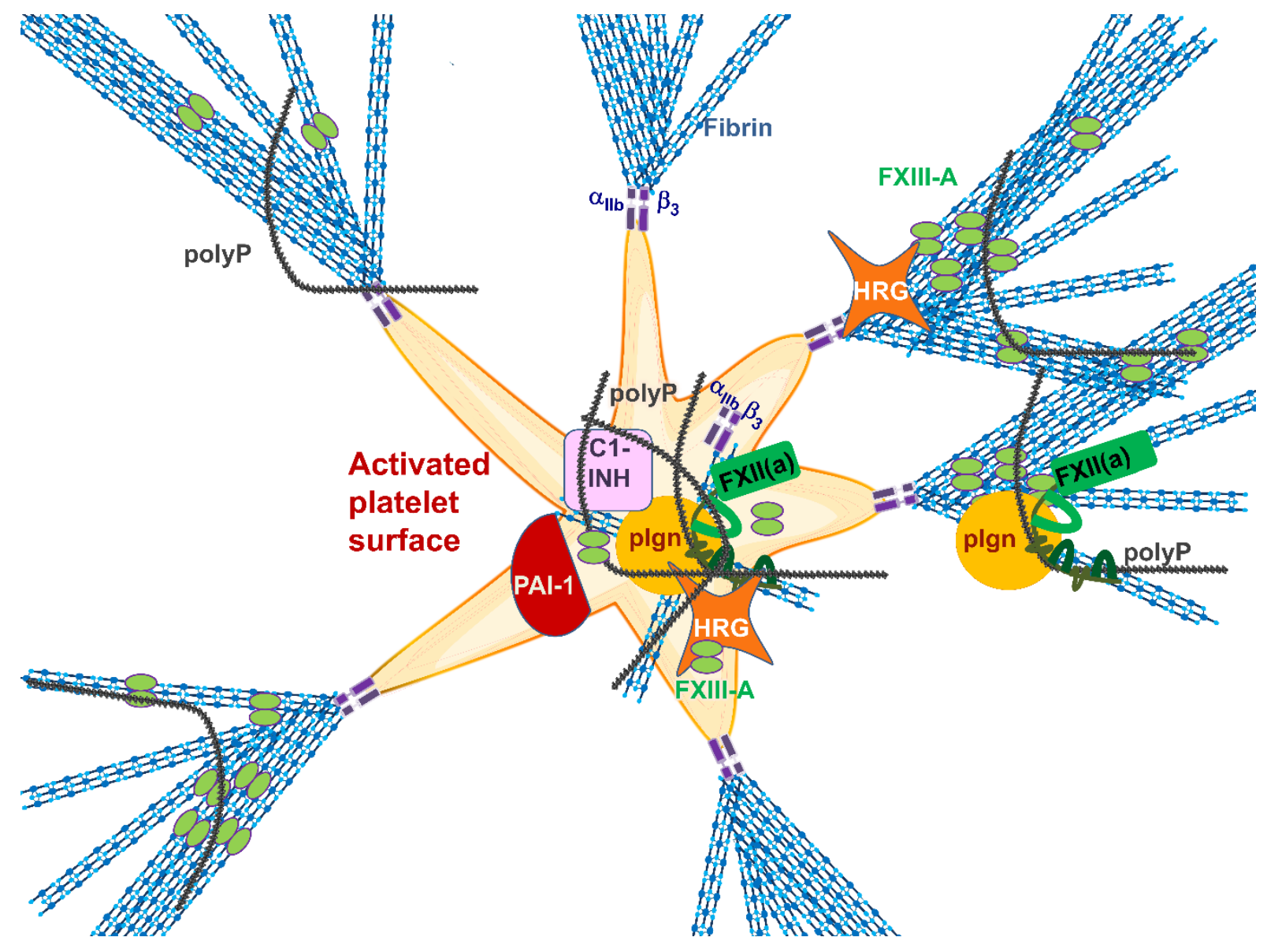


Figure 2B

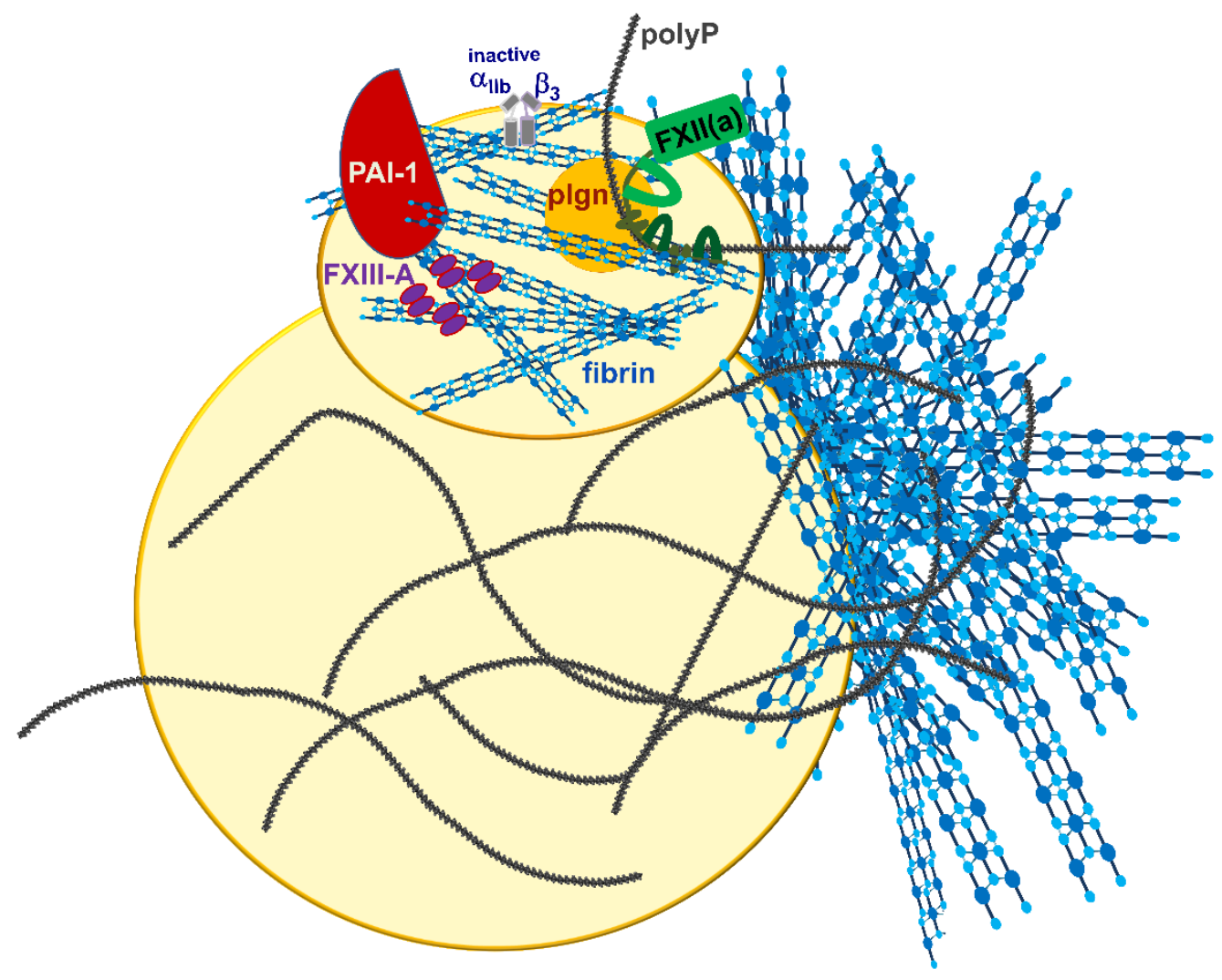


Figure 3

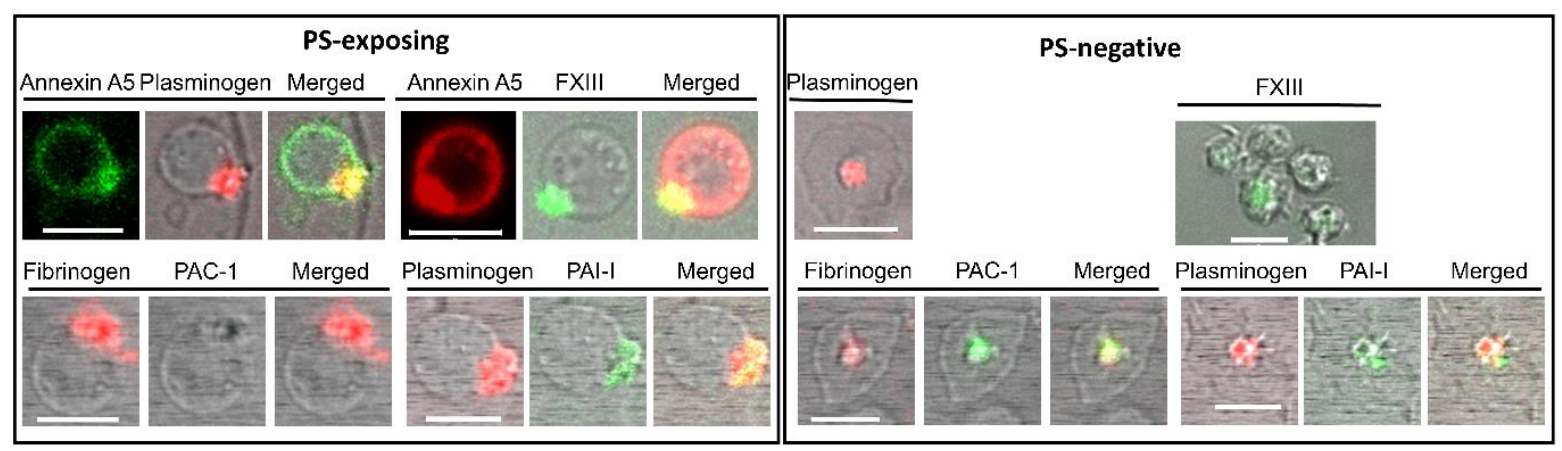


Figure 4
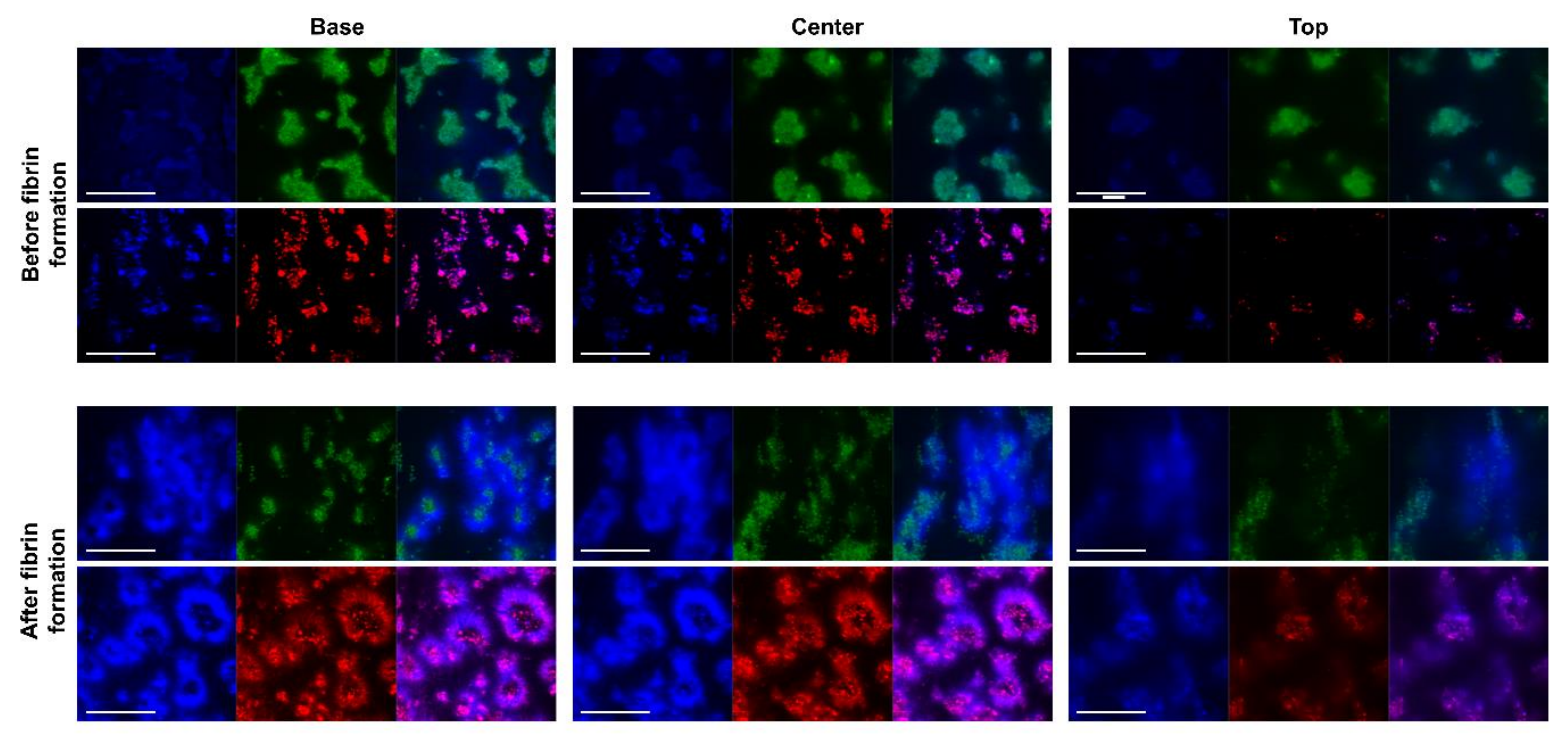
